\title{
Multiproxy constraints on alteration and primary compositions of Ediacaran deep-water carbonate rocks, Yangtze Platform, South China
}

\author{
Simon V. Hohl ${ }^{\mathrm{a}, *}$, Harry Becker ${ }^{\mathrm{a}}$, Steffen Herzlieb ${ }^{\mathrm{a}}$, Qingjun Guo ${ }^{\mathrm{b}}$ \\ ${ }^{\text {a }}$ Freie Universität Berlin, Institut für Geologische Wissenschaften, Malteserstr. 74-100, D-12249 Berlin, Germany \\ ${ }^{\mathrm{b}}$ Center for Environmental Remediation, Institute of Geographic Sciences and Natural Resources Research, Chinese Academy of \\ Sciences, Beijing 100101, China
}

Received 16 June 2014; accepted in revised form 22 April 2015; available online 6 May 2015

\begin{abstract}
The occurrence of shallow and deep-water sedimentary facies has established the Yangtze Platform in South China as a key site for the study of Neoproterozoic ocean oxidation and Ediacaran animal evolution following the Marinoan glaciation. The Yanwutan section in Hunan Province is one of the few coherent sections on the Yangtze Platform where Ediacaran deep-water carbonate sediments (predominantly dolostones) are preserved together with organic carbon-rich shales. Here we present new major and trace element abundance data as well as Sr-, O- and C-isotope compositions of leachates from carbonates of the Doushantuo Formation. We evaluate the role of diagenetic modification of the carbonate rocks and constrain the redox evolution of Ediacaran seawater in space and time. ${ }^{87} \mathrm{Sr} /{ }^{86} \mathrm{Sr}$ systematically varies with $\delta^{18} \mathrm{O}_{\text {carb}}, \mathrm{Sr}-$ and $\mathrm{Ba}$ abundances, indicating variable but mostly strong modification of fluid-mobile elements by continental basin fluids. In contrast, REE + Y patterns have preserved seawater-like compositions. Cap dolostones (unit I) on top of the Nantuo diamictites differ from cap dolostones at shallow-water sections on the Yangtze Platform in that they show no Ce-anomalies, and little alteration near the top $\left({ }^{87} \mathrm{Sr} /{ }^{86} \mathrm{Sr}=0.7078, \delta^{18} \mathrm{O}=-4.0, \delta^{13} \mathrm{C}_{\text {carb }}=1.1\right)$, suggesting that $\delta^{13} \mathrm{C}_{\text {carb }}$ and $\delta^{18} \mathrm{O}$ of cap dolostones at many other sections were compromised by hydrothermal alteration. The overlying organic carbon poor micritic dolostone (unit II) shows negative Ce-anomalies that disappear towards the top of the unit. No Ce-anomalies occur in subsequent organic carbon-rich muddy dolostone units (units III to IV). These observations, enrichments in TOC that correlate with variations in redox-sensitive metals in the carbonates, negative $\delta^{13} \mathrm{C}_{\text {carb }}$ in units II to IV and the decoupling of $\delta^{13} \mathrm{C}_{\mathrm{carb}}$ from $\delta^{13} \mathrm{C}_{\mathrm{org}}$ argue for the existence of mostly anoxic deep-water at the Yangtze passive continental margin during the Ediacaran. The negative Ce-anomalies at the base of unit II (with negative $\delta^{13} \mathrm{C}_{\text {carb }}$ ) may reflect fluctuations towards suboxic or oxic conditions or an allochthonous origin of this unit. However, trace metal enrichments in carbonates of the same unit argue for reducing conditions in pore-water, whereas the carbonates may have preserved the REE $+\mathrm{Y}$ signatures inherited from suboxic- to oxic seawater. The trace element and negative $\delta^{13} \mathrm{C}_{\text {carb }}$ values in units II to IV are consistent with a stratified basin model with a large partially remineralised organic matter reservoir in anoxic bottom and pore-waters.
\end{abstract}

(C) 2015 Elsevier Ltd. All rights reserved.

* Corresponding author. Tel.: +49 (0)30 83870200.

E-mail address: shohl@zedat.fu-berlin.de (S.V. Hohl).

\section{INTRODUCTION}

The terminal Neoproterozoic, also known as the Ediacaran period, was characterized by important global biological and environmental changes: The geological 
record of Ediacaran sediments reveals large variations in carbon isotope compositions (Kaufman et al., 1997; Hoffman et al., 1998; Halverson et al., 2005; Jiang et al., 2007; Guo et al., 2007; Ader et al., 2009) as well as fossil evidence of the appearance of the first animals on Earth (Xiao et al., 2012). The Marinoan glaciation, a major glaciation event of global distribution marks the end of the Cryogenian and the beginning of the Ediacaran with the deposition of cap carbonates on top of glacial sediments at $635 \mathrm{Ma}$ (Le Hir et al., 2009). However the timespan of the global post Marinoan cap carbonate deposition is still a matter of debate (Font et al., 2010; Trindade et al., 2003). The Marinoan glaciation has been evoked by some as a possible cause for some of the subsequent chemical perturbations of the Ediacaran ocean-atmosphere system (Hoffman et al., 1998; Hyde et al., 2000). Several processes have been discussed as triggers for the transition from global glaciation to a greenhouse-like climate that would have been necessary to melt a global (or nearly global) ice sheet. Among these methane clathrate destabilisation by flooding of permafrost meadows (Kennedy et al., 2008) or a proposed elevation in atmospheric $\mathrm{CO}_{2}$ concentrations, producing super-greenhouse warming to melt the ice sheets (Hoffman et al., 1998) are the most promising explanations. Rapid glacial meltdown would lead to a global transgression and super-greenhouse warming would result in intense continental weathering, producing an enormous alkalinity and nutrient flux into the oceans and a lowering in ocean pH (Hoffman et al., 1998; Kasemann et al., 2005). Recent work by Sansjofre et al. (2011) postulated much lower $\mathrm{pCO}_{2}$ levels for the Ediacaran, challenging the super greenhouse rapid meltdown hypothesis of previous authors. Evidence from trace metal data (Lyons et al., 2014 and references therein) indicates anoxic (and locally euxinic) conditions in most parts of the middle to late Neoproterozoic ocean. This hypothesis has been supported by various datasets that show enrichments in redox-sensitive trace elements like U, Mo and V in euxinic black shales (Scott et al., 2008; Sahoo et al., 2012). The input of these elements is largely controlled by the oxidative weathering of crustal minerals and more modest enrichments of these elements occur together with the first geological evidence for increases in atmospheric oxygen (GOE see (Holland, 2006)) or even slightly before (Anbar et al., 2007). A further increase in the abundances of redox sensitive elements in black shales during the late Neoproterozoic is coeval with a second rise in atmospheric and ocean oxygen (Och and Shields-Zhou, 2012). However, the development and vertical extend of the oxygenated surface layer of the oceans during this time remains controversial, as is the timing of large-scale oxygenation of deeper water masses in the oceans.

The Doushantuo Formation (635-551 Ma (Condon et al., 2005)) on the Yangtze Platform, South China, turned out to be one of the key formations for studying ocean oxidation and animal evolution in the aftermath of the Marinoan glaciation. The Doushantuo Formation is comprised of shales, dolomites, limestones and cherts, which are overlying the Nantuo diamictites, deposited at the end of the Marinoan glaciation. It contains a well preserved fossil record (Yuan et al., 2002; Chen and Chi, 2005) and many datasets on carbon, sulphur and strontium isotopes, iron speciation and trace element concentrations were published (Jiang et al., 2006, 2007; Guo et al., 2007; Zhao et al., 2009; Ader et al., 2009; Sawaki et al., 2010; Li et al., 2010, 2013; Huang et al., 2011; Ling et al., 2013). Most previous geochemical studies have focussed on shallow-water facies on the platform margin, especially around the Three Gorges area in Hubei province. To further test a postulated stratified redox model for the Ediacaran oceans (Li et al., 2010; Lyons et al., 2014) and the inferred links to animal evolution (Canfield et al., 2007; McFadden et al., 2008; Xiao et al., 2012) multiproxy studies of carbonate rocks may add valuable information (e.g. Huang et al., 2011; Ling et al., 2013). In the present contribution we evaluate evidence for the vertical extent of oxygenated water masses in the Yangtze basin by study and comparison of major and trace elements and $\mathrm{Sr}, \mathrm{C}$ and $\mathrm{O}$ isotopic compositions of carbonates from the deep-water Yanwutan section, Hunan Province.

Organic or inorganic carbonates precipitated from seawater incorporate the trace element and isotopic compositions of the latter, sometimes with minor, in other cases with significant fractionation (Brand and Veizer, 1980, 1981). During solidification and burial, marine carbonates may be exposed to diagenetic fluids of variable composition and origin, e.g. pore-waters, meteoric or hydrothermal fluids. As ambient conditions and the composition of these fluids are different from seawater, carbonate minerals may partially dissolve in these fluids and reprecipitate as early diagenetic dolomite or late diagenetic low $\mathrm{Mg}$-calcite (Brand and Veizer, 1980). The identification of primary chemical signals of marine precipitates (reflecting seawater chemistry) requires assessing the influence of diagenesis and effects of later fluid-rock interaction on the chemical and isotopic composition of the carbonates.

Trace elements in leachates of carbonate rocks are useful tools for constraining redox conditions in ancient marine environments, in particular if they are combined with isotopic data on the same samples. A detailed analysis of the alteration history of marine carbonates using different elements and isotopic tracers is crucial for interpretation of such data.

The aims of the present study were to distinguish diagenetic overprinting of carbonate rocks from primary, seawater-derived signatures and to constrain compositional variations of Ediacaran seawater in space and time. Our data suggests that in spite of variable diagenetic alteration, one sample at the top of the cap carbonates has ${ }^{87} \mathrm{Sr} /{ }^{86} \mathrm{Sr}=0.70775$ and is close to early Ediacaran seawater values given in Jacobsen and Kaufman (1999) and, compared to other cap carbonates, heavier but not completely unusual stable isotope compositions of -4.0 for $\delta^{18} \mathrm{O}$ and +1.1 for $\delta^{13} \mathrm{C}$ respectively (Brazilian cap carbonates from the Araras platform show similar values (Nogueira et al., 2007). Despite one more sample above the cap carbonates analysed by Guo et al. (2007), the Yanwutan section has been overprinted by a fluid with light oxygen isotopic composition and radiogenic Sr. Since these samples still retain marine seawater REE $+\mathrm{Y}$ patterns, the lanthanides must have been less susceptible to overprinting by diagenetic 
fluid-flow. A further conclusion from the data is that the deep-water of the Yangtze basin may have been anoxic well into the upper Doushantuo.

\section{GEOLOGICAL SETTING}

The Doushantuo Formation is comprised of marine sediments deposited in a passive margin setting along the south-eastern side of the Yangtze Block (Jiang et al., 2011). The deposits are mainly carbonates and carbonate mudstones with interbedded shales and minor phosphorite and chert layers (Zhao, 1985). U-Pb geochronology on zircons of ash beds occurring at the base and top of the Doushantuo Formation have been used to define its duration from $635.2 \pm 0.6 \mathrm{Ma}$ to $551.1 \pm 0.7 \mathrm{Ma}$, spanning almost $90 \%$ of the Ediacaran in South China (Condon et al., 2005).

The lowermost unit of the Doushantuo Formation is a cap carbonate layer of $1-5 \mathrm{~m}$ thickness overlying the Nantuo diamictites of the Marinoan glaciation associated with a significant (but variable) negative carbon isotope excursion (Jiang et al., 2003; Huang et al., 2009), followed by interbedded organic carbon-rich mudstones and dolostones. On shallow-water platform sections the subdivision of the Doushantuo into four general sedimentological facies: DI (cap carbonates), DII (alternating organic carbon rich shales and dolostones topped by a phosphorite layer, DIII (massive banked limestones) and DIV (organic-rich black shales with carbonate concretions and cherts) is now widely used and accepted (McFadden et al., 2008; Zhu et al., 2007). In the deep-water basin sections this subdivision may not be useful because the different depositional environment has led to more shale- and chert-dominated sediment accumulations. The Doushantuo Formation is overlain by massive dolomites of the Dengying Formation on the platform and shales and cherts of the time equivalent Liuochapo Formation in the basin.

The Yanwutan section near the city of Jishou, Hunan province (Fig. 1), is predominantly composed of mudstones and dolostones deposited under slope margin to basin environments (Guo et al., 2007; Zhu et al., 2007) of the Nanhua Basin. This basin was developed along the Yangtze block as a result of the breakup of Rodinia (Wang and Li, 2003) and might have been restricted in its connection to the open ocean.

The Yanwutan section begins with ca. $8 \mathrm{~m}$ of cap dolomites on top of the Nantuo diamictites at the base, followed by $12 \mathrm{~m}$ of organic carbon-rich shale with interbedded mud- and dolostones (Fig. 2). A $35 \mathrm{~m}$ thick unit, starting with a poorly developed basal phosphorite hard ground, followed by organic-poor dolomite pack- and grainstones and organic-rich muddy dolostones, overlies these strata. This unit also includes micritic phosphorites, biolaminations and possibly current related sedimentary structures and was interpreted as a massive submarine slide block of shallow-water origin (Vernhet et al., 2006; Vernhet, 2007). The carbonate unit is overlain by partly brecciated dolostones and mudstones, containing chert layers and nodules $(5 \mathrm{~m})$. According to their stratigraphic position, petrologic description and TOC concentrations we have divided the samples used for this study into four subgroups (see Fig. 2):

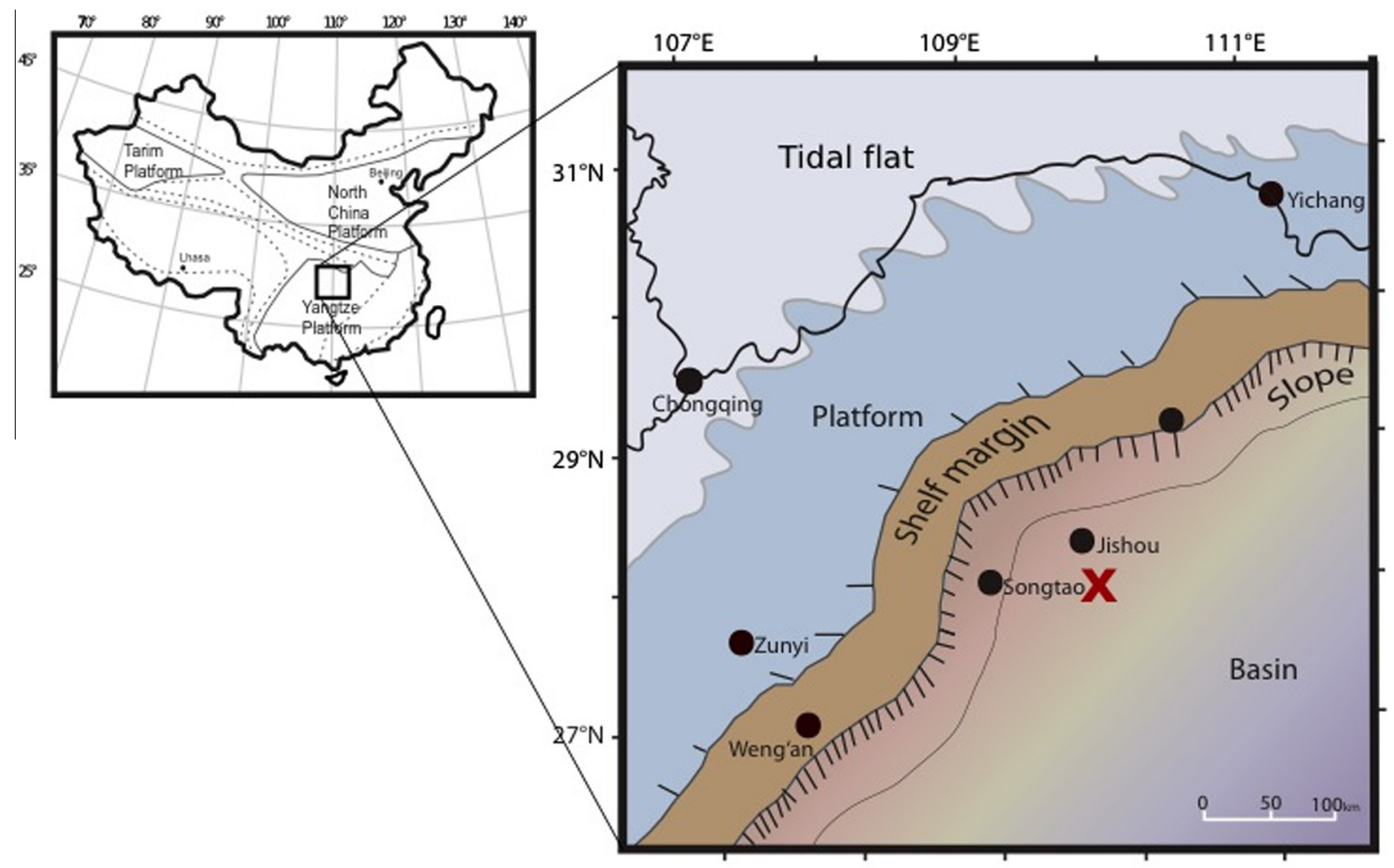

Fig. 1. Location of study area and paleogeographically reconstruction of the platform margin shortly after deposition of the post Marinoan cap carbonates (635 Ma) modified after (Jiang et al., 2011). The cross indicates location of Yanwutan at N28 25.333 E110 28.701. 


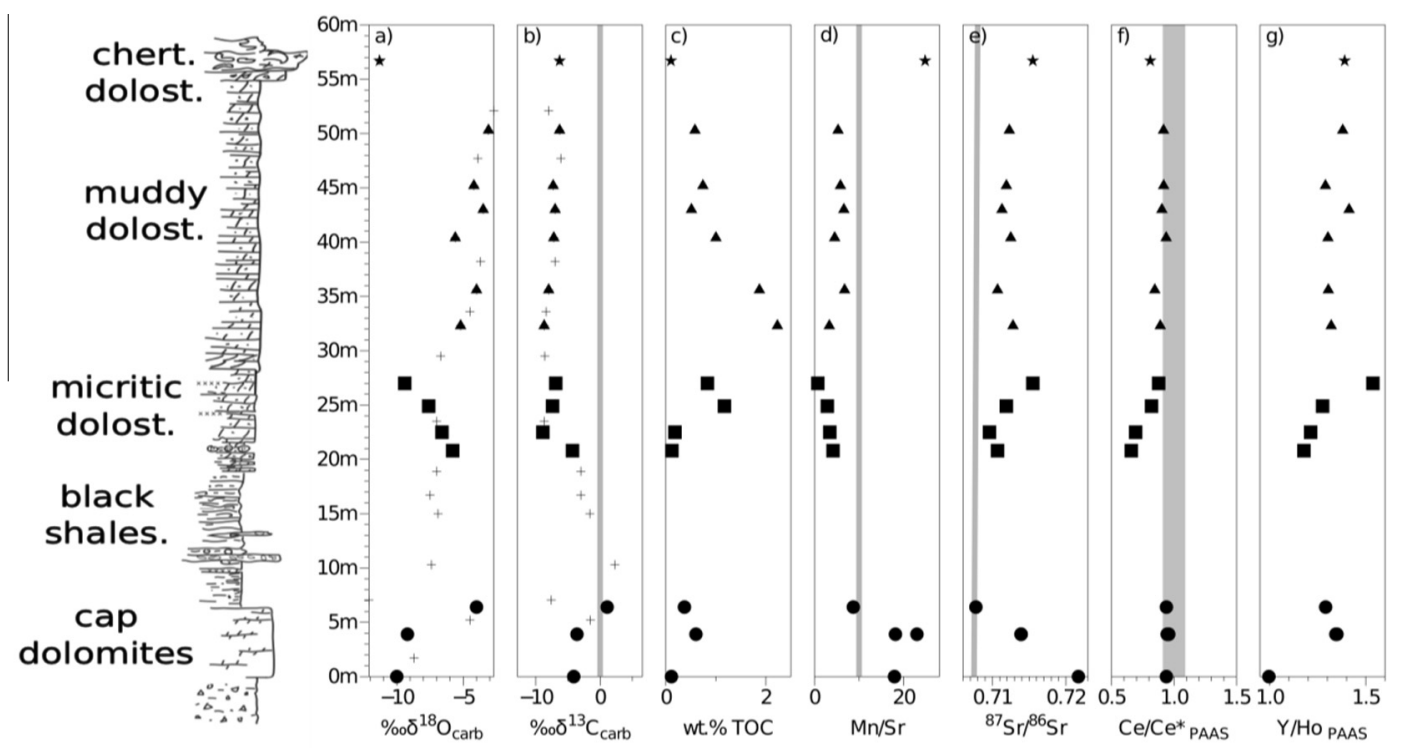

Fig. 2. Stratigraphic profile of the Doushantuo Formation at Yanwutan section. (a-c) $\delta^{18} \mathrm{O}_{\text {carb }}$ and $\delta^{13} \mathrm{C}_{\text {carb }}$ normalised to VPDB and $\%$ TOC (Guo et al., 2007). The filled symbols represent samples studied in this work, the crosses represent the full dataset, one cap dolomite sample plots at $-30 \%$. (d, e) $\mathrm{Mn} / \mathrm{Sr}$ ratios and ${ }^{87} \mathrm{Sr} /{ }^{86} \mathrm{Sr}$. The grey bar marks the Ediacaran seawater composition inferred from least altered marine carbonate rocks (Jacobsen and Kaufman, 1999). (f) $\mathrm{Ce} / \mathrm{Ce}^{*}$ normalised to PAAS, micritic dolostones reveal distinct negative Ce-anomalies. The grey bar indicates the analytical uncertainty. (g) Y/Ho normalised to PAAS indicates strong fractionation in all carbonates except the lowermost cap carbonate (see text).

(I) Cap dolomites

- Massive light grey fine grained dolomitized grainstones with abundant "tepee" structures

(II) Organic carbon-poor dolostone unit

- Fine-sand-grained dolomitized grainstones and packstones with crossbedding structures

(III) Muddy dolostones and organic-rich dolostones

- Dark coloured dolomite with crossbedding interbedded with thinly laminated marls

(IV) Dolostone sample with chert nodules

- Dolomitic breccia with chert bands and chert nodules

The section contains smaller allochthonous slide blocks and olistoliths with a variety of sedimentological facies, such as tepees and ripples which has been used to argue for a shallow-water origin of unit II and III lithologies and mass flow transport of parts of the section into deeper environments (Vernhet et al., 2006, 2007). We note, however, that $\delta^{13} \mathrm{C}_{\text {carb }}$ values are negative at about -4 to -9 throughout the Yanwutan section (Guo et al., 2007) as for other slope or deep-water sections on the Yangtze Platform (Ader et al., 2009). This observation does not support a shallow-water origin of parts of the section, as shallow-platform carbonates of DII to DIV mostly display positive $\delta^{13} \mathrm{C}_{\text {carb }}$ (Ader et al., 2009).

\section{MATERIAL AND METHODS}

We analysed 14 carbonate rocks of the Doushantuo Formation of the Yanwutan section which have been described in detail by (Guo et al., 2007). Carbon and oxygen isotopic compositions of the carbonates were reported by (Guo et al., 2007).

For chemical analysis $20 \mathrm{mg}$ of sample powder were treated with $3 \mathrm{M}$ acetic acid for $12 \mathrm{~h}$ at $70^{\circ} \mathrm{C}$ following Huang et al. (2009). Insoluble residues were separated by centrifugation and filtration through $0.45 \mu \mathrm{m}$ cellulose acetate syringe filters, testing the residues using XRD have shown that the residues are free of any remaining carbonate phases. The supernatant was dried, redissolved in $0.5 \mathrm{ml}$ $3 \mathrm{M} \mathrm{HNO}_{3}$, and dried again to remove the remaining acetic acid. Finally the precipitate was redissolved in $1 \mathrm{ml} 0.28 \mathrm{M}$ $\mathrm{HNO}_{3}$, weighed and diluted with $0.28 \mathrm{M} \mathrm{HNO} 3$ to $1: 20.000$ for trace element and to 1:40.000 for major element analysis. All measurements were performed on a Thermo Finnigan Element XR sector-field ICP mass spectrometer at Freie Universität Berlin using a Scott type quartz spray chamber and a $100 \mu \mathrm{l} / \mathrm{min}$ nebulizer. Sample time was $120 \mathrm{~s}$ with 20 samples/peak and 60 total scans. With this analytical setup tuning generally yielded low oxide rates of $2-5 \% \mathrm{CeO}^{+}$and less than $1 \% \mathrm{BaO}^{+}$. We determined element concentrations by external calibration to the matrix-matching CAL-S carbonate standard (Yeghicheyan et al., 2003). For drift correction the diluted samples were doped with solutions of $2 \mathrm{ppb}$ In and $1 \mathrm{ppb}$ $\mathrm{Tl}$ for elements analysed in low resolution mode (REE, $\mathrm{Y}, \mathrm{Rb}, \mathrm{Pb}, \mathrm{Sr}, \mathrm{Mo}, \mathrm{Cd}, \mathrm{In}, \mathrm{Tl}, \mathrm{P}, \mathrm{Th}, \mathrm{U})$, and $12.5 \mathrm{ppb}$ $\mathrm{Co}$ for elements analysed in medium resolution mode ( $\mathrm{Mg}, \mathrm{Al}, \mathrm{Ca}, \mathrm{Mn}, \mathrm{Cr}, \mathrm{Fe}, \mathrm{Co}, \mathrm{K}, \mathrm{V}, \mathrm{Zn}, \mathrm{Ti})$. Background corrections were performed by subtraction of the raw intensities of aspirated $0.28 \mathrm{M} \mathrm{HNO}_{3}$. The analytical precisions were usually better than $5 \%$ RSD for most REE, Y, Rb, $\mathrm{Cd}, \mathrm{Ti}, \mathrm{Zn}, \mathrm{Ba}, \mathrm{Pb}, \mathrm{Mg}, \mathrm{Al}, \mathrm{Ca}, \mathrm{Mn}, \mathrm{K}, \mathrm{Th}, 10 \%$ for $\mathrm{Sr}$, $\mathrm{U}, \mathrm{V}, \mathrm{Fe}$ and $\mathrm{La}$ and above $10 \% \mathrm{RSD}$ for $\mathrm{Cr}$ and Mo. 
The limit of detection on LREE was $100-620 \mathrm{pg} / \mathrm{g}$ and $16-240 \mathrm{pg} / \mathrm{g}$ on HREE. Procedural blanks on most trace elements and REE were negligible. Limit of detection for redox sensitive elements $\mathrm{U}, \mathrm{V}$ and Mo was $1.4-4.5 \mathrm{ng}$, for $\mathrm{Ba}, \mathrm{Mg}, \mathrm{Mn}$ and $\mathrm{Fe} 12-26 \mathrm{ng}$, and for $\mathrm{Sr} 200 \mathrm{ng}$. Procedural blanks of major and trace elements were generally below the acid background signal intensities.

Aliquots of the acetic acid leachates were used for $\mathrm{Sr}$ isotopic composition measurements. Approximately $1 \mu \mathrm{g} \mathrm{Sr}$ was loaded in $2.5 \mathrm{M} \mathrm{HCl}$ on $1 \mathrm{ml} \mathrm{AG} 50 \mathrm{~W}-\mathrm{X} 8(200-400$ mesh) cation-exchange resin for separation of $\mathrm{Sr}$ from the matrix.

The Strontium isotopic composition was determined using a Thermo-Finnigan Triton TIMS at FU Berlin. Repeated measurements of SRM 987 yielded ${ }^{87} \mathrm{Sr} /{ }^{86} \mathrm{Sr}=$ $0.710266( \pm 15, n=6)$. Mass fractionation was corrected assuming a ${ }^{86} \mathrm{Sr} /{ }^{88} \mathrm{Sr}$ ratio $=0.1194(\mathrm{Nier}, 1938)$ and the exponential law. Minor interferences of ${ }^{87} \mathrm{Rb}$ on ${ }^{87} \mathrm{Sr}$ were corrected using ${ }^{85} \mathrm{Rb} /{ }^{87} \mathrm{Rb}=2.59265$. Initial ${ }^{87} \mathrm{Sr} /{ }^{86} \mathrm{Sr}$ were calculated assuming depositional ages $(600 \mathrm{Ma}),{ }^{87} \mathrm{Rb} /{ }^{86} \mathrm{Sr}$ ratios (calculated from ICP-MS data) and a half-life of ${ }^{87} \mathrm{Rb}$ of $4.88 \times 10^{10}$ years. Corrections of radiogenic ingrowth were usually between 0.01 and $0.5 \%$ except YAW505 were the correction due to the ingrowth of $\mathrm{Rb}$ decay is on the order of $2 \%$. In general corrections are minor and do not change the interpretation of the carbonate data.

\section{RESULTS}

\section{1. $\mathrm{Sr}$ isotopic compositions}

The ${ }^{87} \mathrm{Sr} /{ }^{86} \mathrm{Sr}$ isotopic compositions of the cap dolomites (Table 1) range from 0.72170 at the base of the micritic cap dolomite unit to 0.70775 at the top at $6.4 \mathrm{~m}$. The organic carbon-poor dolostone unit (from 20.8 to $27 \mathrm{~m}$ stratigraphic height) shows ${ }^{87} \mathrm{Sr} /{ }^{86} \mathrm{Sr}$ between 0.70964 and 0.71547. The third unit, comprised of dolostones, muddy dolostones, or organic-rich dolostones also shows high ${ }^{87} \mathrm{Sr} /{ }^{86} \mathrm{Sr}$ of $0.71071-0.71281$. The cherty dolostone at the top of the Yanwutan section has ${ }^{87} \mathrm{Sr} /{ }^{86} \mathrm{Sr}$ of 0.71547 .

\subsection{Major and trace element concentrations}

Major and trace element concentrations in acetic acid leachates of Yanwutan section display considerable variations (Table 1) making them the perfect samples to describe not only Precambrian seawater chemistry but also effects of early and late rock diagenesis. Major element concentrations of $\mathrm{Ca}, \mathrm{Mg}, \mathrm{Mn}$ and $\mathrm{Fe}$ were used to calculate hypothetical dolomite mass fractions (Table 1), assuming that during dolomitisation, $\mathrm{Mg}^{2+}, \mathrm{Fe}^{2+}$ and $\mathrm{Mn}^{2+}$ will substitute for $\mathrm{Ca}^{2+}$ in $\mathrm{CaCO}_{3}$, forming stoichiometric dolomite $\mathrm{Ca}(\mathrm{Mg}, \mathrm{Mn}, \mathrm{Fe})\left(\mathrm{CO}_{3}\right)_{2}$. Typically samples show 18-21 wt.\% $\mathrm{Ca}$ and 9-12 wt.\% Mg, whereas the lowermost cap carbonate in unit I (YAW 500) contains only $3.8 \mathrm{wt} . \% \mathrm{Ca}$ and 0.9 wt. $\% \mathrm{Mg}$, and unit IV sample YAW 535 having only 2.6 wt. $\%$ Ca. All analysed carbonate rocks are dolostones with just minor proportions of calcite in the matrix. Samples with very low bulk $\mathrm{Ca}$ and $\mathrm{Mg}$ contents are siliciclastic rocks rather than carbonates. The carbonate samples have very low Al contents $(<1200 \mu \mathrm{g} / \mathrm{g})$ with only the lowermost cap carbonate YAW 500 exceeding $3000 \mu \mathrm{g} / \mathrm{g} \mathrm{Al}$ and low $\mathrm{Rb}$ contents $(<1.1 \mu \mathrm{g} / \mathrm{g})$ with $2.3 \mu \mathrm{g} / \mathrm{g}$ in YAW 500, this together with elevated $\mathrm{K}$ content $(3600 \mu \mathrm{g} / \mathrm{g})$ argues for partial leaching of alkali bearing silicates in this sample.

Manganese displays large variations throughout the profile. Concentrations of $\mathrm{Mn}$ of around $670 \mu \mathrm{g} / \mathrm{g}$ at the base increase to $2800 \mu \mathrm{g} / \mathrm{g}$ in overlying cap dolomites and return to values between $290-650 \mu \mathrm{g} / \mathrm{g}$ in the carbonates of units II and III. The sample of unit IV shows a slight increase again to $960 \mu \mathrm{g} / \mathrm{g}$. Fe contents in cap dolomites are generally high $(350-440 \mu \mathrm{g} / \mathrm{g})$ but show non-systematic variations, with unit IV showing the highest value with $689 \mu \mathrm{g} / \mathrm{g}$ Fe.

$\mathrm{Sr}$ and $\mathrm{Ba}$ concentrations display large variations throughout the profile (Sr 37-880 $\mu \mathrm{g} / \mathrm{g}, \mathrm{Ba} 24-690 \mu \mathrm{g} / \mathrm{g}$ ) and carbonates also show high variability in their $\mathrm{Pb}$ concentrations $(5.9-238 \mu \mathrm{g} / \mathrm{g})$ with the highest concentrations in the cap dolomites and a gradual decrease throughout the profile.

The Yanwutan cap dolomites (like elsewhere on the Yangtze Platform) have undergone carbonate diagenesis. They yield high $\mathrm{Mn} / \mathrm{Sr}$ ratios of 17-23 with the uppermost sample YAW 505 showing a lower value of 8.7. The cap dolomites show increasing concentrations of $\mathrm{Sr}$ from 38 to $319 \mu \mathrm{g} / \mathrm{g}$ and increasing $\delta^{18} \mathrm{O}$ values from -10 to -4 from base to top. $\mathrm{Mn} / \mathrm{Sr}$ shows a positive correlation with ${ }^{87} \mathrm{Sr} /{ }^{86} \mathrm{Sr}$ values $(0.72170$ at the base to 0.70775 at the top) and a negative correlation with $\delta^{18} \mathrm{O}$ (Fig. 2). Unit II and III show no correlations of isotopic tracers with $\mathrm{Mn} / \mathrm{Sr}$, which tend to be lower than data for the cap dolomites $(<10)$. The $\mathrm{Mn} / \mathrm{Sr}$ ratios in unit II are decreasing with stratigraphic height from 4 to 0.8 , with variable $\mathrm{Sr}$ contents from 138 to $832 \mu \mathrm{g} / \mathrm{g}$ and relatively constant concentrations in $\mathrm{Mn}(400-650 \mu \mathrm{g} / \mathrm{g}) . \delta^{18} \mathrm{O}$ values range between -9.4 and -6.9 . $\mathrm{Mn} / \mathrm{Sr}$ ratios in unit III range from 3 to 7 , having low Sr $(60-108 \mu \mathrm{g} / \mathrm{g})$ and variable $\mathrm{Mn}$ concentrations (293$649 \mu \mathrm{g} / \mathrm{g})$ and decreasing $\delta^{18} \mathrm{O}$ values down to -2.7 . The chert-rich dolomitic sample of unit IV has elevated $\mathrm{Mn} / \mathrm{Sr}$ of 25 with very low $\mathrm{Sr}$ abundances of $38 \mu \mathrm{g} / \mathrm{g}, \delta^{18} \mathrm{O}$ of -11.3 and ${ }^{87} \mathrm{Sr} /{ }^{86} \mathrm{Sr}$ ratio of 0.71547 and seems to be the most altered sample. The sample with the lowest ${ }^{87} \mathrm{Sr} /{ }^{86} \mathrm{Sr}$, a cap dolomite with the heaviest $\delta^{13} \mathrm{C}_{\mathrm{carb}}$ in the section, plots close to the inferred ${ }^{87} \mathrm{Sr} /{ }^{86} \mathrm{Sr}$ of Ediacaran seawater derived from little altered carbonate rocks from other Ediacaran profiles around the world (Jacobsen and Kaufman, 1999; Halverson et al., 2010) and has a $\mathrm{Mn} / \mathrm{Sr}$ below 10 .

There is no correlated decrease of $\delta^{18} \mathrm{O}$ with $\delta^{13} \mathrm{C}$ nor a correlation of $\mathrm{Mn} / \mathrm{Sr}$ with light stable isotopic data (Guo et al., 2007) or ${ }^{87} \mathrm{Sr} /{ }^{86} \mathrm{Sr}$ isotopic ratios. We note a correlation of increasing ${ }^{87} \mathrm{Sr} /{ }^{86} \mathrm{Sr}$ and decreasing $\mathrm{Sr}$ concentration and $\delta^{18} \mathrm{O}$ for the two lower units II and I.

Before discussing the results of the rare earth elements and $\mathrm{Y}$, analytical limitations and normalization procedures for the calculation and evaluation of $\mathrm{Eu}$ and Ce-anomalies are warranted. It has been shown that $\mathrm{Eu}$ concentration measurements on the ICP-MS are strongly affected by 
Table 1

Major and trace elemental data Yanwutan.

\begin{tabular}{|c|c|c|c|c|c|c|c|c|c|c|c|c|c|c|c|}
\hline & $\begin{array}{l}\text { YAW500 } \\
\text { cap } \\
\text { dolost.unit I }\end{array}$ & $\begin{array}{l}\text { YAW503A } \\
\text { cap dolost } \\
\text { unit I }\end{array}$ & $\begin{array}{l}\text { YAW503B } \\
\text { cap dolost } \\
\text { unit I }\end{array}$ & $\begin{array}{l}\text { YAW505 } \\
\text { cap dolost } \\
\text { unit I }\end{array}$ & $\begin{array}{l}\text { YAW518 } \\
\text { dolost.unit } \\
\text { II }\end{array}$ & $\begin{array}{l}\text { YAW519 } \\
\text { dolost.unit } \\
\text { II }\end{array}$ & $\begin{array}{l}\text { YAW521 } \\
\text { org-rich dst } \\
\text { unit II }\end{array}$ & $\begin{array}{l}\text { YAW522 } \\
\text { dolost unit } \\
\text { II }\end{array}$ & $\begin{array}{l}\text { YAW524 } \\
\text { muddy dst } \\
\text { unit III }\end{array}$ & $\begin{array}{l}\text { YAW526 } \\
\text { muddy dst } \\
\text { unit III }\end{array}$ & $\begin{array}{l}\text { YAW528 } \\
\text { dolost unit } \\
\text { III }\end{array}$ & $\begin{array}{l}\text { YAW529 } \\
\text { muddy dst } \\
\text { unit III }\end{array}$ & $\begin{array}{l}\text { YAW530 } \\
\text { muddy dst } \\
\text { unit III }\end{array}$ & $\begin{array}{l}\text { YAW532 } \\
\text { muddy dst } \\
\text { unit III }\end{array}$ & $\begin{array}{l}\text { YAW535 } \\
\text { muddy dst } \\
\text { unit IV }\end{array}$ \\
\hline $\begin{array}{l}\text { Stratigraphic } \\
\text { position }[\mathrm{m}]\end{array}$ & $0-0.3$ & 3.9 & 3.9 & 6.4 & 20.8 & 22.5 & 24.9 & 27 & 32.3 & 35.6 & 40.4 & 43 & 45.2 & 50.3 & 56.7 \\
\hline $\mathrm{Rb} \mu \mathrm{g} / \mathrm{g}$ & 2.3 & 0.56 & 0.53 & 0.74 & 0.53 & 0.35 & 0.29 & 0.08 & 0.71 & 0.65 & 0.56 & 1.08 & 1.04 & 0.48 & 0.06 \\
\hline $\mathrm{Sr} \mu \mathrm{g} / \mathrm{g}$ & 37 & 155 & 118 & 319 & 137 & 187 & 141 & 833 & 88 & 60 & 118 & 90 & 108 & 123 & 39 \\
\hline $\mathrm{Ba} \mu \mathrm{g} / \mathrm{g}$ & 75.8 & 24.1 & 24.4 & 691.9 & 243.8 & 236.8 & 56.8 & 14.5 & 30.2 & 67 & 75.2 & 60.1 & 42.4 & 29.2 & 32.8 \\
\hline $\mathrm{Y} \mu \mathrm{g} / \mathrm{g}$ & 2.68 & 6.71 & 4.49 & 13.42 & 2.44 & 1.35 & 2.86 & 5.72 & 5.06 & 4.41 & 4.04 & 3.27 & 4.07 & 3.16 & 0.87 \\
\hline $\mathrm{Cd} \mu \mathrm{g} / \mathrm{g}$ & 1.96 & 0.8 & 0.62 & 2.98 & 2.41 & 16.7 & 0.77 & 1.06 & 3.51 & 7.36 & 0.91 & 1.46 & 2.37 & 1.09 & 0.88 \\
\hline $\mathrm{La} \mu \mathrm{g} / \mathrm{g}$ & 0.79 & 2.56 & 1.81 & 3.5 & 0.89 & 0.48 & 2.02 & 1.4 & 2.83 & 2.4 & 1.72 & 2.13 & 2.54 & 2.02 & 0.16 \\
\hline $\mathrm{Ce} \mu \mathrm{g} / \mathrm{g}$ & 2.12 & 5.43 & 3.83 & 8.32 & 1.33 & 0.9 & 3.06 & 2.64 & 4.77 & 3.64 & 3.28 & 3.8 & 4.87 & 3.53 & 0.45 \\
\hline $\operatorname{Pr} \mu \mathrm{g} / \mathrm{g}$ & 0.3 & 0.69 & 0.48 & 1.13 & 0.26 & 0.15 & 0.4 & 0.38 & 0.6 & 0.46 & 0.42 & 0.44 & 0.57 & 0.41 & 0.08 \\
\hline $\mathrm{Nd} \mu \mathrm{g} / \mathrm{g}$ & 1.39 & 2.85 & 2.01 & 5 & 1.13 & 0.63 & 1.45 & 1.66 & 2.34 & 1.71 & 1.71 & 1.61 & 2.08 & 1.49 & 0.4 \\
\hline Sm $\mu \mathrm{g} / \mathrm{g}$ & 0.45 & 0.73 & 0.54 & 1.52 & 0.29 & 0.16 & 0.29 & 0.53 & 0.58 & 0.38 & 0.44 & 0.34 & 0.44 & 0.34 & 0.11 \\
\hline $\mathrm{Eu} \mu \mathrm{g} / \mathrm{g}^{1}$ & 0.102 & 0.213 & 0.149 & 0.386 & 0.052 & 0.038 & 0.073 & 0.233 & 0.119 & 0.077 & 0.092 & 0.075 & 0.104 & 0.069 & 0.026 \\
\hline $\mathrm{Gd} \mu \mathrm{g} / \mathrm{g}$ & 0.51 & 0.87 & 0.61 & 1.77 & 0.31 & 0.18 & 0.33 & 0.64 & 0.64 & 0.44 & 0.48 & 0.39 & 0.48 & 0.36 & 0.12 \\
\hline $\mathrm{Tb} \mu \mathrm{g} / \mathrm{g}$ & 0.09 & 0.146 & 0.1 & 0.316 & 0.055 & 0.032 & 0.058 & 0.114 & 0.107 & 0.079 & 0.087 & 0.063 & 0.084 & 0.061 & 0.019 \\
\hline$D y \mu g / g$ & 0.55 & 0.89 & 0.6 & 1.97 & 0.35 & 0.19 & 0.37 & 0.71 & 0.67 & 0.54 & 0.55 & 0.41 & 0.55 & 0.4 & 0.12 \\
\hline Но $\mu \mathrm{g} / \mathrm{g}$ & 0.099 & 0.183 & 0.122 & 0.382 & 0.076 & 0.041 & 0.082 & 0.137 & 0.141 & 0.124 & 0.114 & 0.085 & 0.116 & 0.084 & 0.023 \\
\hline $\operatorname{Er} \mu \mathrm{g} / \mathrm{g}$ & 0.27 & 0.55 & 0.36 & 1.07 & 0.24 & 0.13 & 0.26 & 0.38 & 0.41 & 0.4 & 0.34 & 0.26 & 0.34 & 0.26 & 0.07 \\
\hline $\mathrm{Tm} \mu \mathrm{g} / \mathrm{g}$ & 0.037 & 0.076 & 0.051 & 0.149 & 0.036 & 0.02 & 0.04 & 0.05 & 0.058 & 0.062 & 0.049 & 0.037 & 0.05 & 0.038 & 0.01 \\
\hline $\mathrm{Yb} \mu \mathrm{g} / \mathrm{g}$ & 0.25 & 0.52 & 0.34 & 1.01 & 0.26 & 0.14 & 0.27 & 0.3 & 0.38 & 0.44 & 0.32 & 0.25 & 0.34 & 0.26 & 0.06 \\
\hline $\mathrm{Lu} \mu \mathrm{g} / \mathrm{g}$ & 0.037 & 0.085 & 0.056 & 0.151 & 0.039 & 0.022 & 0.042 & 0.041 & 0.053 & 0.067 & 0.049 & 0.038 & 0.051 & 0.039 & 0.009 \\
\hline $\mathrm{Zn} \mu \mathrm{g} / \mathrm{g}$ & 167 & 246 & 136 & 286 & 63 & 116 & 46 & 80 & 50 & 122 & 104 & 116 & 101 & 40 & 18 \\
\hline $\mathrm{Pb} \mu \mathrm{g} / \mathrm{g}$ & 238 & 35 & 33 & 53 & 44 & 21 & 8 & 6 & 23 & 16 & 20 & 21 & 30 & 28 & 11 \\
\hline $\mathrm{P} \mu \mathrm{g} / \mathrm{g}$ & 139 & 142 & 180 & 327 & 519 & 288 & 95 & 66 & 196 & 184 & 236 & 231 & 249 & 238 & 405 \\
\hline $\mathrm{U} \mu \mathrm{g} / \mathrm{g}$ & 0.33 & 0.37 & 0.37 & 2.91 & 0.35 & 0.07 & 0.29 & 0.53 & 0.41 & 0.63 & 2.83 & 0.59 & 30.03 & 1.24 & 1.71 \\
\hline $\mathrm{Th} \mu \mathrm{g} / \mathrm{g}$ & 0.57 & 0.36 & 0.4 & 0.74 & 0.17 & 0.19 & 0.15 & 0.08 & 0.41 & 0.29 & 0.37 & 0.39 & 0.66 & 0.35 & 0.03 \\
\hline Mo $\mu \mathrm{g} / \mathrm{g}$ & 0.45 & 0.49 & 0.28 & 0.58 & 0.1 & 0.06 & 0.07 & 0.26 & 0.04 & 0.05 & 0.39 & 0.11 & 0.52 & 0.12 & 4.55 \\
\hline $\mathrm{V} \mu \mathrm{g} / \mathrm{g}$ & 2.52 & 10.3 & 10.1 & 21.9 & 24.7 & 15.7 & 11.6 & 22.7 & 38.9 & 88.8 & 52.8 & 56.9 & 45.8 & 52.6 & 3.2 \\
\hline $\mathrm{Cr} \mu \mathrm{g} / \mathrm{g}$ & 4.95 & 4.68 & 4.52 & 5.4 & 16.68 & 5.31 & 4.06 & 4.23 & 19.4 & 24.4 & 11 & 11.9 & 9.2 & 3.9 & 28.2 \\
\hline Ti $\mu \mathrm{g} / \mathrm{g}$ & b.d.1. & 35 & 19 & 217 & 25 & 41 & 19 & 31 & b.d.l. & b.d.l. & 18 & 30 & 79 & 33 & b.d.l. \\
\hline $\mathrm{Mn} \mu \mathrm{g} / \mathrm{g}$ & 669 & 2809 & 2716 & 2774 & 575 & 639 & 405 & 630 & 294 & 403 & 532 & 591 & 627 & 649 & 961 \\
\hline $\mathrm{Fe} \mu \mathrm{g} / \mathrm{g}$ & 436 & 395 & 410 & 347 & 157 & 88.6 & 156 & 439 & 79.1 & 112 & 184 & 121 & 134 & 123 & 687 \\
\hline $\mathrm{K} \mu \mathrm{g} / \mathrm{g}$ & 3668 & 998 & 1032 & 1859 & 884 & 521 & 454 & 106 & 1221 & 1204 & 821 & 1264 & 1491 & 690 & 715 \\
\hline Mg wt.\% & 0.90 & 12 & 11.7 & 10.6 & 11.1 & 12.1 & 9.8 & 12 & 10.6 & 11.6 & 9 & 12 & 11.4 & 12 & 0.3 \\
\hline Al wt.\% & 0.32 & 0.12 & 0.12 & 0.2 & 0.1 & 0.08 & 0.05 & 0.03 & 0.12 & 0.11 & 0.07 & 0.12 & 0.13 & 0.07 & 0.01 \\
\hline Ca wt.\% & 3.79 & 21.3 & 20.6 & 18.9 & 19.7 & 21.4 & 17.8 & 21.4 & 18.4 & 20.5 & 16.3 & 20.6 & 19.9 & 21 & 2.63 \\
\hline $\mathrm{Mn} / \mathrm{Fe}$ & 1.53 & 7.11 & 6.62 & 8 & 3.66 & 7.21 & 2.59 & 1.44 & 3.71 & 3.59 & 2.88 & 4.88 & 4.7 & 5.27 & 1.4 \\
\hline $\mathrm{Mn} / \mathrm{Sr}$ & 17.9 & 18.1 & 23 & 8.7 & 4.1 & 3.4 & 2.9 & 0.8 & 3.3 & 6.7 & 4.5 & 6.6 & 5.8 & 5.3 & 24.8 \\
\hline Dolomite & 59 & 97 & 97 & 97 & 96 & 96 & 95 & 96 & 97 & 97 & 95 & 98 & 97 & 97 & 38 \\
\hline
\end{tabular}

wt. \%

$\begin{array}{lllllllll}{\mathrm{Ce} / \mathrm{Ce}^{* 2}}^{{ }^{*}} & 0.94 & 0.94 & 0.96 & 0.94 & 0.66 & 0.69 & 0.82 & 0.88 \\ \mathrm{Eu} / \mathrm{Eu}^{{ }_{3}} & 1.03 & 1.32 & 1.29 & 1.14 & 0.84 & 1.07 & 1.15 & 1.97\end{array}$

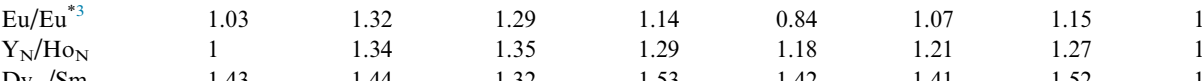

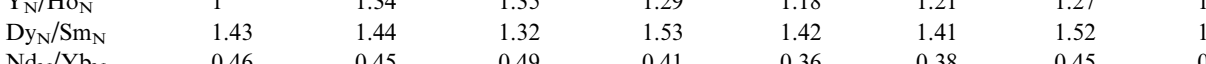

$\begin{array}{llllllll}0.88 & 0.89 & 0.85 & 0.94 & 0.9 & 0.92 & 0.92 & 0.81 \\ .97 & 0.96 & 0.97 & 0.96 & 1.03 & 1.09 & 0.96 & 1.11 \\ .54 & 1.32 & 1.31 & 1.3 & 1.41 & 1.29 & 1.38 & 1.39 \\ .61 & 1.37 & 1.68 & 1.48 & 1.43 & 1.48 & 1.41 & 1.24 \\ 0.46 & 0.52 & 0.32 & 0.44 & 0.53 & 0.51 & 0.48 & 0.58\end{array}$

$\begin{array}{llllllll}0.46 & 0.52 & 0.32 & 0.44 & 0.53 & 0.51 & 0.48 & 1.24 \\ 0.715467 & 0.71281 & 0.7071 & 0.712518 & 0.71268 & 0.71906 & 0.71225 & 0.715472\end{array}$

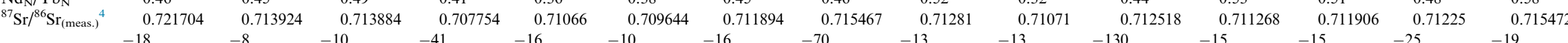




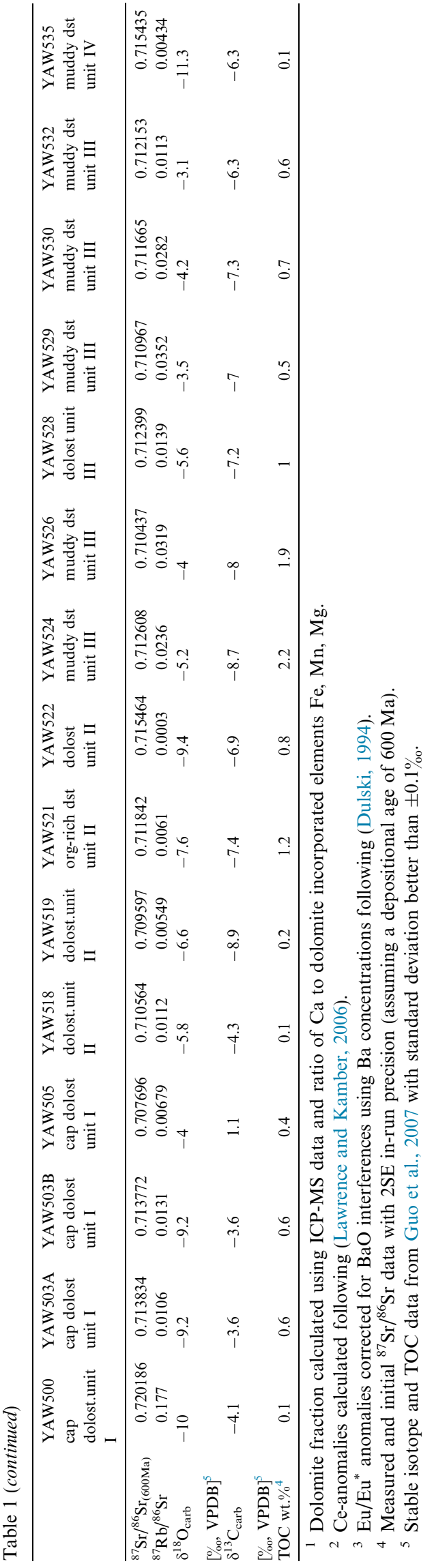

interfering $\mathrm{BaO}^{+}$molecules (Dulski, 1994). If these molecular interferences are not corrected for, a diagram of $\mathrm{Ba} / \mathrm{Nd}$ vs. $\mathrm{Eu} / \mathrm{Eu}^{*}$ (calculated according to $\mathrm{Eu} / \mathrm{Eu}^{*}=$ $\mathrm{Eu}_{\mathrm{N}} /\left(\mathrm{Sm}_{\mathrm{N}}^{2} * \mathrm{~Tb}_{\mathrm{N}}\right)^{1 / 3}$, see below) will show a positive correlation, indicating analytical artefacts on $\mathrm{Eu}$ abundance measurements (Electronic Supplement Fig. A). Our Eu data therefore was corrected by using the measured $\mathrm{Ba}$ concentration and oxide formation rates following the equations given by Dulski (1994). After correction of these artefacts, most samples have no Eu-anomalies within the range of analytical uncertainty. The REE $+\mathrm{Y}$ patterns were normalised relative to PAAS (McLennan, 1989) and are shown in Fig. 3. Values for $\mathrm{Ce} / \mathrm{Ce}^{*}$ and $\mathrm{Eu} / \mathrm{Eu}^{*}$ were calculated following the equations given in Lawrence and Kamber (2006): $\mathrm{Ce} / \mathrm{Ce}^{*}=\mathrm{Ce}_{\mathrm{N}} /\left(\operatorname{Pr}_{\mathrm{N}}{ }^{*} \operatorname{Pr}_{\mathrm{N}} / \mathrm{Nd}_{\mathrm{N}}\right)$ and $\mathrm{Eu} / \mathrm{Eu}^{*}=\mathrm{Eu}_{\mathrm{N}} /$ $\left(\mathrm{Sm}_{\mathrm{N}}^{2} * \mathrm{~Tb}_{\mathrm{N}}\right)^{1 / 3}$

These equations avoid using $\mathrm{La}$ and $\mathrm{Gd}$ for the calculation of $\mathrm{Ce} / \mathrm{Ce}^{*}$ and $\mathrm{Eu} / \mathrm{Eu}^{*}$, because these elements may be enriched by natural processes, and thus may cause apparent depletions in $\mathrm{Ce}$ and Eu anomalies, respectively (Ling et al., 2013). In unit II the most negative Ce-anomalies appear $\left(\mathrm{Ce} / \mathrm{Ce}^{*} \approx 0.7\right.$, Fig. 2) where increasing $\mathrm{Mn} / \mathrm{Fe}$ is anti-correlated with $\mathrm{Ce} / \mathrm{Ce}^{*}$. All other units show no or only slightly negative $\mathrm{Ce} / \mathrm{Ce}^{*}(0.9-1.0)$. All analysed carbonate leachates have seawater-like REE $+\mathrm{Y}$ patterns (Fig. 3) with relative enrichment of HREE over LREE. Furthermore, positive $\mathrm{Y}$ anomalies are prevalent, with normalised $\mathrm{Y} / \mathrm{Ho}_{\mathrm{PAAS}}$ varying between 1.2 and 1.5 (except YAW 500 for which no $\mathrm{Y}$ anomaly was found).

\section{DISCUSSION}

\subsection{Post-depositional diagenesis of carbonates}

In this section we discuss possible influences of late fluid-flow interaction on fluid-mobile trace elements and $\mathrm{C}, \mathrm{O}$ and $\mathrm{Sr}$ isotopic compositions of the Yanwutan carbonate rocks following approaches in the literature (Derry, 2010; Brand and Veizer, 1981; Derry et al., 1989; Banner and Hanson, 1990; Jacobsen and Kaufman, 1999). Studies of carbonate diagenesis in Phanerozoic rocks (Brand and Veizer, 1980) generally observed elevated contents of $\mathrm{Mn}^{2+}, \mathrm{Fe}^{2+}$ and $\mathrm{Zn}^{2+}$ and decreasing contents of $\mathrm{Sr}^{2+}, \mathrm{Na}^{2+}$ and $\mathrm{Mg}^{2+}$ due to dissolution of primary $\mathrm{CaCO}_{3}$ and precipitation of carbonate cements under the influence of meteoric diagenesis. In the presence of meteoric fluids, the partition coefficient of $\mathrm{Sr}^{2+}$ between calcite and water $\mathrm{K}_{\text {calcite/water }}$ is $<1$ and $\mathrm{K}_{\text {calcite/water }}$ for $\mathrm{Mn}^{2+}$ is $>1$ (Banner and Hanson, 1990). Therefore when discussing the influence of diagenesis on ancient carbonates, $\mathrm{Mn} / \mathrm{Sr}$ ratios are commonly used to estimate the influence of diagenetic overprinting. Kaufman and Knoll (1995) proposed that Proterozoic carbonate samples with $\mathrm{Mn} / \mathrm{Sr}$ ratio $<10$ might still retain their primary $\delta^{13} \mathrm{C}$ signatures. Yanwutan carbonate leachates from different units reveal a broad variation in $\mathrm{Mn} / \mathrm{Sr}$ ratios but also in their Sr concentrations. Despite the cap dolomites and unit IV cherty dolomite, all Yanwutan $\mathrm{Mn} / \mathrm{Sr}$ ratios are below 10. In some cases however, Mn may behave more conservatively, whereas $\mathrm{Sr}$ is preferentially leached during the exchange with late 

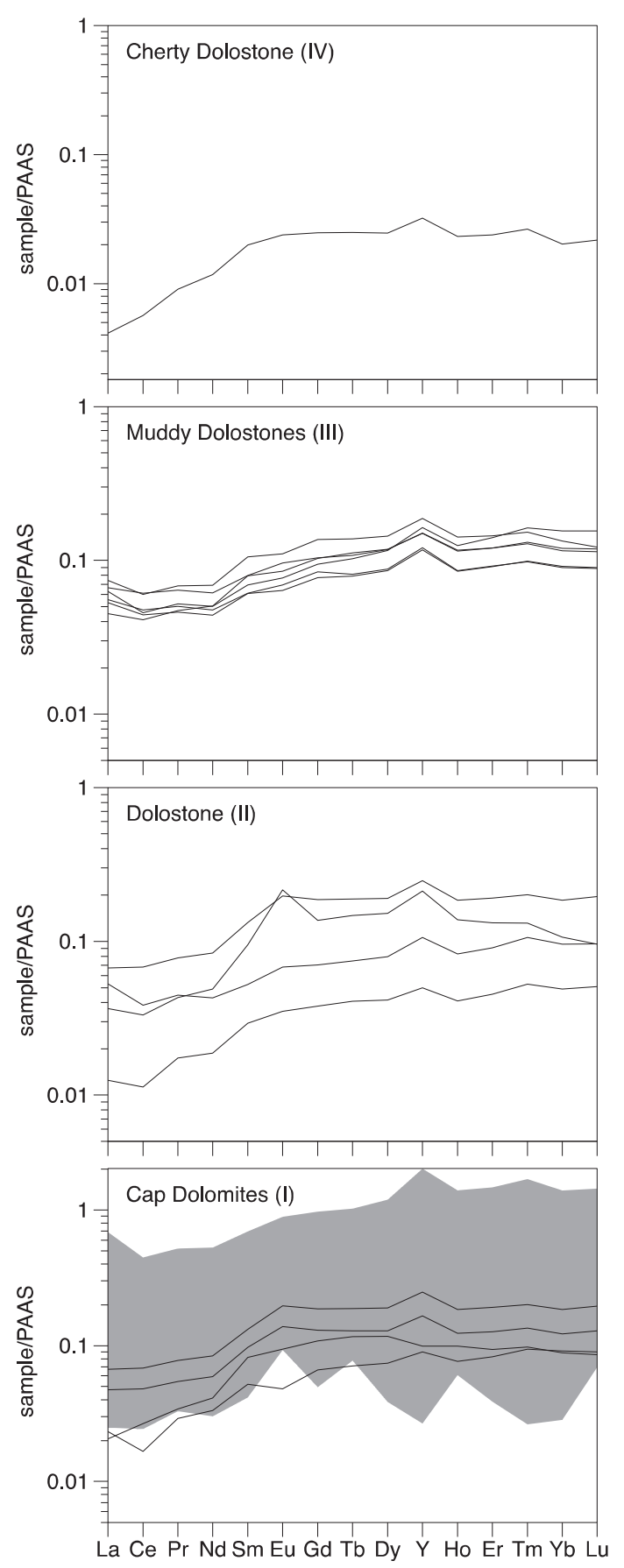

Fig. 3. REE $+Y$ patterns of leachates of carbonate rocks from Yanwutan units I to IV, normalised to PAAS (McLennan, 1989). Units correspond to their positions in the section from base to top. Grey field in unit I shows data from Jiulongwan cap carbonates (Huang et al., 2009), revealing a much broader REE+Y variation. All samples throughout the Yanwutan section show fractionation of HREE over LREE with Y anomalies being present in most of the samples (except the lowermost cap carbonate), indicating their marine origin. Negative Ce-anomalies can be seen in unit II, whereas an apparent anomaly in unit $\mathrm{I}$ is due to enrichment in La which can be assessed by calculating the real anomalies following (Lawrence and Kamber, 2006) (see Fig. 3). Note that Eu has been corrected for interferences from $\mathrm{BaO}$ following (Dulski, 1994) and shows no resolvable anomalies. fluids, leading to an increase of the $\mathrm{Mn} / \mathrm{Sr}$ ratios as it can be seen at the bade of unit I. Therefore reliance on $\mathrm{Mn} / \mathrm{Sr}$ ratios alone may sometimes be misleading in rocks with large variations in their $\mathrm{Sr}$ concentration.

Late fluid flow and diagenesis can significantly change the stable isotope composition of carbonate rocks (Brand and Veizer, 1981). The isotopic exchange between pore fluids and the carbonate minerals will generally shift $\delta^{18} \mathrm{O}$ in carbonates towards lower values than those of seawater because oxygen is abundant in aqueous fluids and the latter often contain oxygen originally derived from isotopically light meteoric precipitation (Brand and Veizer, 1981; Banner and Hanson, 1990; Jacobsen and Kaufman, 1999). Knauth and Kennedy (2009) proposed that lithification processes lead to a conjugate decrease in both $\delta^{13} \mathrm{C}$ and $\delta^{18} \mathrm{O}$, however, in detail, correlations are rarely clear and both isotopic systems are often decoupled (Electronic Supplement Fig. B). In many studies it has been argued that both $\delta^{13} \mathrm{C}$ and $\delta^{18} \mathrm{O}$ changed during post depositional diagenesis (e.g. Derry, 2010), but in some cases, primary compositions may still be preserved in carbonate rocks (Stoll and Schrag, 2000; Tahata et al., 2013). The Yanwutan samples show significant variation in $\delta^{13} \mathrm{C}(+2$ to -9$)$ and $\delta^{18} \mathrm{O}$ $(-3$ to -12$)$ (Guo et al., 2007), however no co-variation of $\delta^{13} \mathrm{C}$ and $\delta^{18} \mathrm{O}$ exists (Electronic Supplement Fig. B). The range and magnitude of the negative $\delta^{13} \mathrm{C}_{\text {carb }}$ is not unusual in Ediacaran deep-water dolomites (e. g., Ader et al., 2009) and extreme light values have been explained by either primary carbonate precipitation during bacterial sulphate reduction processes (Van Lith et al., 2003), the presence of methanotrophic biomass (Ader et al., 2009) or the vicinity of methane seeps and the reaction with $\delta^{13} \mathrm{C}$-depleted hydrocarbon fluids (e.g. Jiang et al., 2003). Furthermore the Yanwutan section presumably comprises the time range of the Shuram-Wonoka anomaly, which represents the largest relative change in $\delta^{13} \mathrm{C}_{\text {carb }}$ in geologic time (e.g. Kaufman and Knoll, 1995 and references therein). This worldwide occurring anomaly has been explained as a large-scale perturbation and upwelling event of a large pool of dissolved organic carbon in deep-water of the Ediacaran ocean (Fike et al., 2006; Grotzinger et al., 2011), or, alternatively, as a secondary diagenetic signal in the sedimentary record (Derry, 2010; Macouin et al., 2012).

Alteration of the $\mathrm{Sr}$ isotopic system could either be due to in situ mobilization of radiogenic $\mathrm{Sr}$ from silicate phases by pore-water or by externally derived fluids. Alternatively, external fluids percolating through clastic sediments or continental basement may have increased the ${ }^{87} \mathrm{Sr} /{ }^{86} \mathrm{Sr}$ ratios of the sediments by precipitation of secondary carbonate minerals. Because $\mathrm{Sr}$ is a fluid-mobile element, its concentrations may decrease in secondary carbonates that formed after reaction with fluids in open systems (Brand and Veizer, 1981).

The Yanwutan dataset seem to have at least two samples in the cap dolostones and at the base of unit II that are presumably close to pristine Ediacaran compositions $\left(\delta^{13} \mathrm{C}=1.1, \delta{ }^{18} \mathrm{O}=-4\right)$ (see Fig. 2) and $\mathrm{Sr}$ isotopic composition $\left({ }^{87} \mathrm{Sr} /{ }^{86} \mathrm{Sr}=0.70775\right.$ in the cap dolostone). Those values can be compared to datasets published for the relatively undisturbed Brazilian Marinoan cap carbonates of 

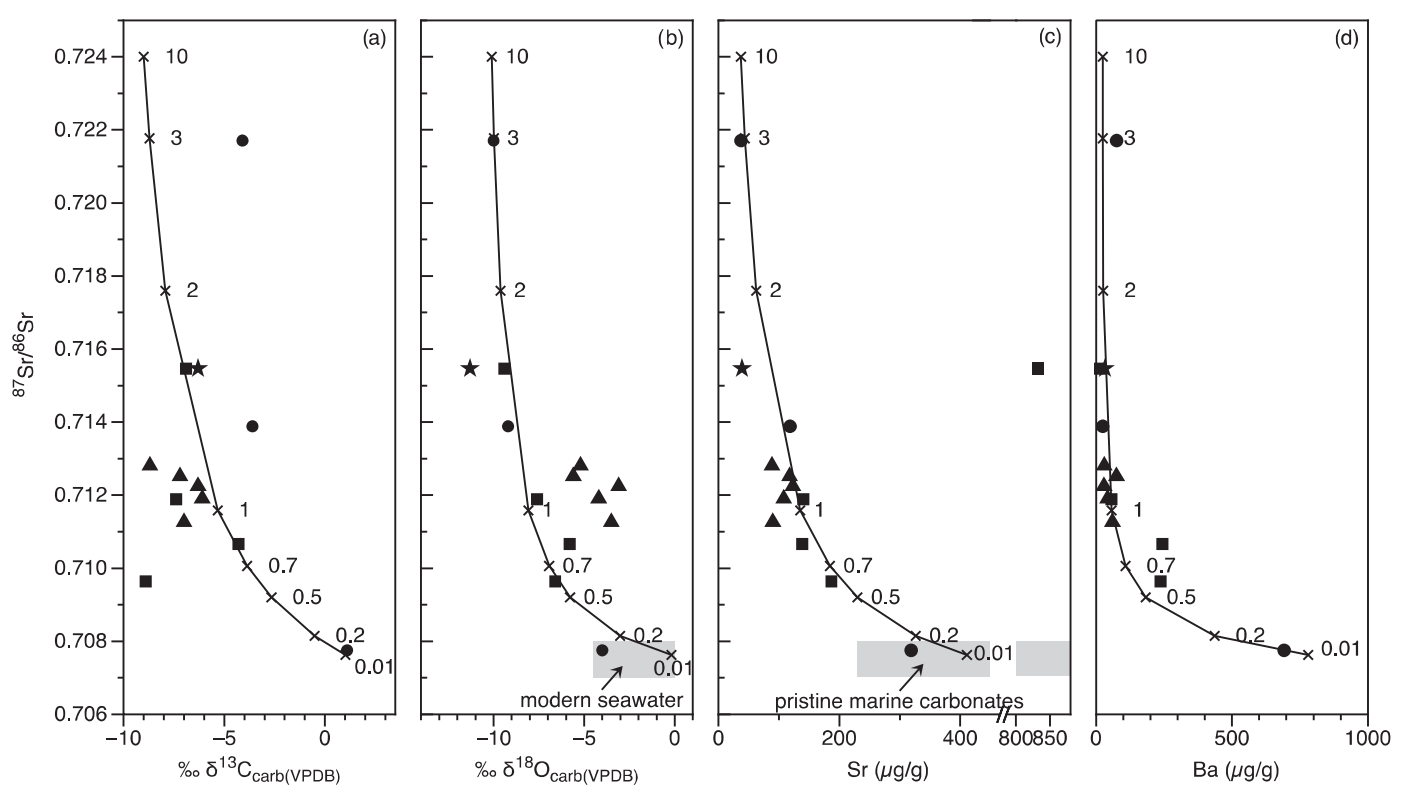

Fig. 4. (a-d) Open system fluid-carbonate mixing model for Ediacaran carbonate rocks from units I to IV from the Yanwutan section following Jacobsen and Kaufman, 1999. Variable fluid-rock ratios (crosses on the line) with a distinct fluid composition of ${ }^{87} \mathrm{Sr} /{ }^{86} \mathrm{Sr}$ of 0.7074 and a presumed original carbonate composition of $\delta^{18} \mathrm{O}$ of $0, \delta^{13} \mathrm{C}$ of $1.5,330 \mu \mathrm{g} / \mathrm{g} \mathrm{Sr}$ and $700 \mu \mathrm{g} / \mathrm{g}$ Ba was used in the model. (Circles: cap dolomites - unit I; squares: micritic dolostones - unit II; triangles: carbon rich dolostones - unit III; star: cherty dolostone - unit IV). Note that variations of unit I and II in ${ }^{87} \mathrm{Sr} /{ }^{86} \mathrm{Sr}$ and $\delta^{18} \mathrm{O}$ concentrations match for an open system fluid mixing (b), whereas unit III plots above the curve, indicating either a different fluid source or variable enrichments of the fluid in radiogenic Sr. Variations of increasing Sr and $\mathrm{Ba}$ concentrations with increasing ${ }^{87} \mathrm{Sr} /{ }^{86} \mathrm{Sr}$ for all samples $\left(\mathrm{c}+\mathrm{d}\right.$ ). Variations in $\delta^{13} \mathrm{C}$ do not match for most of the units (except the cap dolomites) with the proposed model mixing curve (a).

the Mirassol d'Oeste and Guia formations $\left(\delta^{13} \mathrm{C}=-5.2\right.$ to $-1.5, \delta^{18} \mathrm{O}=$ up to -5.3 and ${ }^{87} \mathrm{Sr} /{ }^{86} \mathrm{Sr}=0.7074$ to 0.7080$)$ (Nogueira et al., 2007; Sansjofre et al., 2011).

In order to assess the influence of fluid overprint on $\mathrm{Sr}$ and oxygen isotopes of the pristine carbonates, we have fitted an open system fluid-rock mixing model (Jacobsen and Kaufman, 1999) to our isotopic and mobile element concentration data (Fig. 5). As a starting point for the model, the pristine marine carbonate composition, the following values were used: ${ }^{87} \mathrm{Sr} /{ }^{86} \mathrm{Sr}$ of $0.7074, \delta^{13} \mathrm{C}$ of 1.1 and $700 \mu \mathrm{g} / \mathrm{g} \mathrm{Ba}$ (inferred from the most pristine sample of our dataset). Values for $\delta{ }^{18} \mathrm{O}(0), \operatorname{Sr}(330 \mu \mathrm{g} / \mathrm{g})$ and $\mathrm{C}$ $(1200 \mu \mathrm{g} / \mathrm{g})(J a c o b s e n$ and Kaufman, 1999) were taken as values for Neoproterozoic marine carbonate compositions. For the model we use variable fluid/rock ratios (0.01-10) and a 'continental' fluid composition with $80 \mu \mathrm{g} / \mathrm{g} \mathrm{Ba}$, $50 \mu \mathrm{g} / \mathrm{g} \quad \mathrm{Sr}$ and $1000 \mu \mathrm{g} / \mathrm{g} \quad \mathrm{C}, \quad{ }^{87} \mathrm{Sr} /{ }^{86} \mathrm{Sr}=0.7240, \quad \delta$ ${ }^{18} \mathrm{O}_{\text {carb }}=-13.5 \%$ and $\delta^{13} \mathrm{C}_{\text {carb }}=-12 \%$ (Jacobsen and Kaufman, 1999). The mixing model provides a good fit to most of the Yanwutan carbonate rocks (unit I and II and possibly III) and is consistent with other evidence for post-depositional hydrothermal overprinting (Huang et al., 2011). Data of unit III do not match the model well in that they show relative higher ${ }^{87} \mathrm{Sr} /{ }^{86} \mathrm{Sr}$ values for given $\delta^{18} \mathrm{O}$ and slightly lower $\mathrm{Sr}$ concentrations. This may be explained by lower $\mathrm{Sr}$ concentrations and higher ${ }^{87} \mathrm{Sr} /{ }^{86} \mathrm{Sr}$ in the fluid that affected unit III. Unit IV sample overlaps in its ${ }^{87} \mathrm{Sr} /{ }^{86} \mathrm{Sr}$ composition with the model but has a lower $\delta^{18} \mathrm{O}$ value, a low $\mathrm{Sr}$ content and the highest $\mathrm{Mn} / \mathrm{Sr}$ ratio, which might be explained by subsequent meteoric fluid overprint with a different composition. In order to model variations in the Ba content of the samples, concentrations of Ba much higher than in Phanerozoic carbonates $(>700 \mu \mathrm{g} / \mathrm{g})$ must be assumed for the precursor rocks. This may be explained by early diagenetic Ba enrichments in pore-waters due to anoxic conditions near the seafloor and bacterial sulphate reduction. Assuming such higher initial $\mathrm{Ba}$ concentrations in carbonates, later post-diagenetic fluid flow will then lead to similar trends of mobile element leaching as for $\mathrm{Sr}$ (Fig. 4 c, d). Modelling the variations in $\delta^{13} \mathrm{C}$ is only successful for the cap carbonate samples all other units are offset from the model curve and plot in a cluster rather than a curved trend. Clearly, the $\delta^{13} \mathrm{C}$ signature in most Yanwutan carbonates is decoupled from fluid-mobile elements. Furthermore $\delta^{18} \mathrm{O}$ and ${ }^{87} \mathrm{Sr} /{ }^{86} \mathrm{Sr}$ do not reveal any correlations with any of the seawater $\mathrm{REE}+\mathrm{Y}$ proxies such as $\mathrm{Y} / \mathrm{Ho}$ or $\mathrm{Pr} / \mathrm{Yb}$ (see Electronic Supplement Fig. C).

\subsection{Origin of abundance variations in $\mathbf{R E E}+\mathrm{Y}$}

Here we discuss the potential use of REE $+\mathrm{Y}$ in carbonates as paleo-environment proxies and possible influences on them by leaching or dissolution of silicates and other detrital phases.

The rare earth elements and $\mathrm{Y}$ substitute for $\mathrm{Ca}^{2+}$ in carbonate lattices. It has been shown that REE+Y signals in non-skeletal marine carbonates of modern and ancient seawater can preserve the composition of coeval seawater (Banner, 1988; Webb and Kamber, 2000). Although REE can be susceptible to diagenetic alteration (Palmer, 1985; Sholkovitz and Shen, 1995) solid state diffusion is minimal 


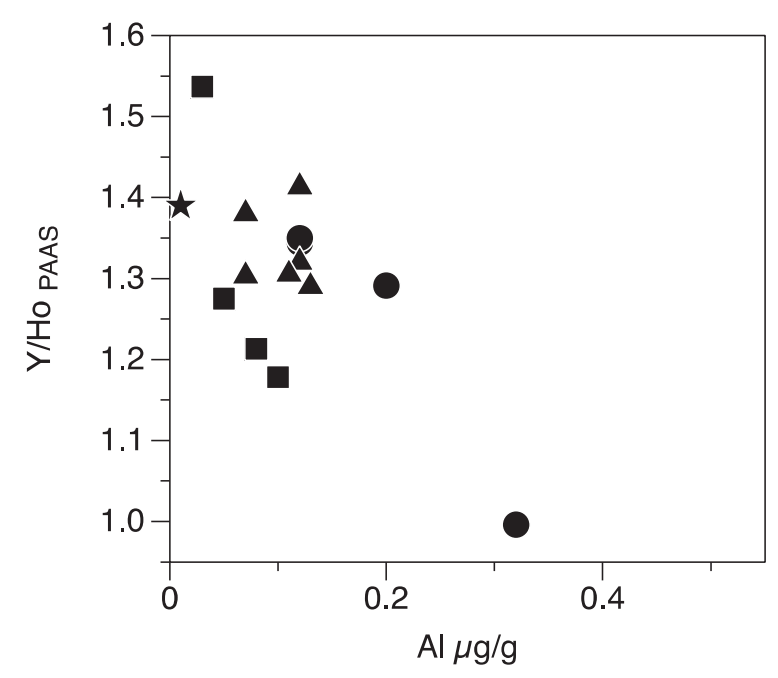

Fig. 5. With the exception of a cap dolomite all $\mathrm{Y} / \mathrm{Ho}$ ratios are superchondritic. A Negative correlation of Al concentrations with $\mathrm{Y} / \mathrm{Ho}$ ratios occurs in the cap dolomites (dots) and in rocks from unit II (squares).

even under metamorphic conditions (Cherniak, 1998). Because of the low concentrations of these elements in fresh water, meteoric alteration should not influence the REE $+Y$ patterns in carbonate rocks significantly and consequently many ancient dolomite rocks may record $\mathrm{REE}+\mathrm{Y}$ patterns of coeval seawater (Webb et al., 2009).

The REE + Y patterns obtained by acetic acid leaching of carbonates from Yanwutan reveal typical seawater-like patterns with significant relative enrichment of the HREE over the LREE and negative Ce-anomalies (Fig. 3). The concentrations of the REE and $\mathrm{Y}$ in these leachates seem not to be influenced by leaching of silicate phases since no correlation of these proxies with $\mathrm{Al}$ or Ti concentrations can be found in the samples. We note that the isotopically most pristine cap dolomite shows the highest total REE concentration of all carbonate rocks analysed here. We also found a weak positive correlation $\left(R^{2}=0.85\right)$ between total $\mathrm{REE}$ and $\mathrm{Al}$ concentrations in the muddy dolostone and cherty dolostone samples of units III and IV. This may be explained by limited acetic acid leaching of aluminosilicate minerals such as clays. Furthermore we use $\mathrm{Nd} / \mathrm{Yb}_{\text {PAAs }}$ ratios to monitor any MREE enrichment that is typical for apatite leaching (Nothdurft et al., 2004). Nd/Yb $\mathrm{b}_{\text {PAAS }}$ ratios are generally low $(<0.6)$ and display no correlation with $\mathrm{P}$ concentrations, arguing against phosphate leaching (Shields and Stille, 2001).

Throughout the profile $\mathrm{Y} / \mathrm{Ho}$ ratios are superchondritic but do not reach values typical for modern marine carbonates of about 60-90 (Nozaki et al., 1997) The highest Y/Ho ratio in Yanwutan carbonates is 42.3 in unit III. However these values are close to previously published maximum values for $\mathrm{Y} / \mathrm{Ho}$ in Doushantuo carbonates (e.g. Huang et al., 2009, 2011; Ling et al., 2013). Superchondritic, but relatively low $\mathrm{Y} / \mathrm{Ho}$ ratios may be a result of seawater/freshwater mixing (Lawrence and Kamber, 2006). Y/Ho ratios within the cap dolomites at Yanwutan (unit I) and in unit II show negative correlations with
Al concentrations, presumably resulting from dilution of seawater with freshwater maybe caused by slow melting of icebergs along with increased continental REE input (Fig. 5.).

To test for hydrothermal input, Eu-anomalies (PAAS normalised) were calculated following Lawrence and Kamber (2006). A positive Eu-anomaly could denote an enrichment of $\mathrm{Eu}^{2+}$ in the water column, due to the reduction of the element in reducing high-temperature fluids (e.g. Derry and Jacobsen, 1990). With the possible exception of the uppermost sample of unit II, interference-corrected Eu data of Yanwutan section show no resolvable Eu-anomalies, suggesting no or negligible mixing of seawater with ocean-ridge derived hydrothermal fluids or subsequent alteration by such fluids (Electronic Supplement Fig. A). In sections of the Three Gorges area the impact of high temperature reducing fluids on the cap carbonates was inferred from positive Eu-anomalies (Huang et al., 2009) and clumped isotope data (Bristow et al., 2012). Temperatures of up to $200{ }^{\circ} \mathrm{C}$ in the D2 units of the Doushantuo Formation have been determined from illite cristallinity (Derkowski et al., 2013). The fluid source is unclear, however a reducing hydrothermal MORB fluid can be ruled out given the geologic position of the Neoproterozoic Yangtze Platform on a passive continental margin and the absence of basalts within the sedimentary rocks (Wang and Li, 2003).

In order to test the robustness of our $\mathrm{Ce}$ data and the inferred Ce-anomalies we use two different approaches. Following (Shields and Stille, 2001) we use $\mathrm{Dy}_{\mathrm{N}} / \mathrm{Sm}_{\mathrm{N}}$ ratios to test if Ce-anomalies are influenced by MREE enrichment. $\mathrm{Dy}_{\mathrm{N}} / \mathrm{Sm}_{\mathrm{N}}$ ratios at Yanwutan are all $>1$ and show no correlation with $\mathrm{Ce} / \mathrm{Ce}^{*}$, arguing for the robustness of the cerium data in this section. To test if an anomalous La-anomaly may be affecting the $\mathrm{Ce} / \mathrm{Ce}^{*}$ ratios, Bau et al. (1996) proposed a method which is additionally checking for $\operatorname{Pr}$ anomalies using $\operatorname{Pr} / \operatorname{Pr}^{*}=2 \operatorname{Pr}_{N}^{*}\left(\mathrm{Ce}_{\mathrm{N}}+\mathrm{Nd}_{\mathrm{N}}\right)$. $\operatorname{Pr} / \mathrm{Pr}^{*} \geqslant 1$ can only be caused by a real negative $\mathrm{Ce}$-anomaly since there are no natural ways to produce an $\mathrm{Nd}$ anomaly and thus the Ce deficiency is not due to an anomalous behaviour of neighbouring La. With the exception of the cap carbonates, all other samples plot in the field of $\mathrm{Ce} / \mathrm{Ce}^{*}<0.95$ and $\mathrm{Pr} / \mathrm{Pr}^{*}<1.05(5 \%$ error on the REE analysis), i.e. they have a negative Ce-anomaly (Fig. 6).

Modern oxic aquatic systems show strong negative Ce-anomalies (PAAS-normalised) in their dissolved load. The Ce deficiency in the water results from the preferential scavenging of $\mathrm{Ce}^{\mathrm{IV}} \mathrm{O}_{2}$ by $\mathrm{Mn}$ - and Fe-rich oxides and hydroxides (Elderfield et al., 1988; Byrne and Kim, 1990; Alibo and Nozaki, 1999). In deeper suboxic to anoxic waters Ce-anomalies diminish due to the dissolution of settling oxides (German et al., 1991). Areas of preferred $\mathrm{Mn}^{2+}$ oxidation like at the oxic/suboxic boundary in the Black Sea therefore show strong association of REE and Mn. In contrast, the uptake of REE by $\mathrm{Fe}^{3+}$ oxides is typically associated with submarine hydrothermal plume activity (German et al., 1991; Ling et al., 2013). Ling et al. (2013) showed that Ediacaran carbonates throughout the Doushantuo formation of shallow-water sections record 


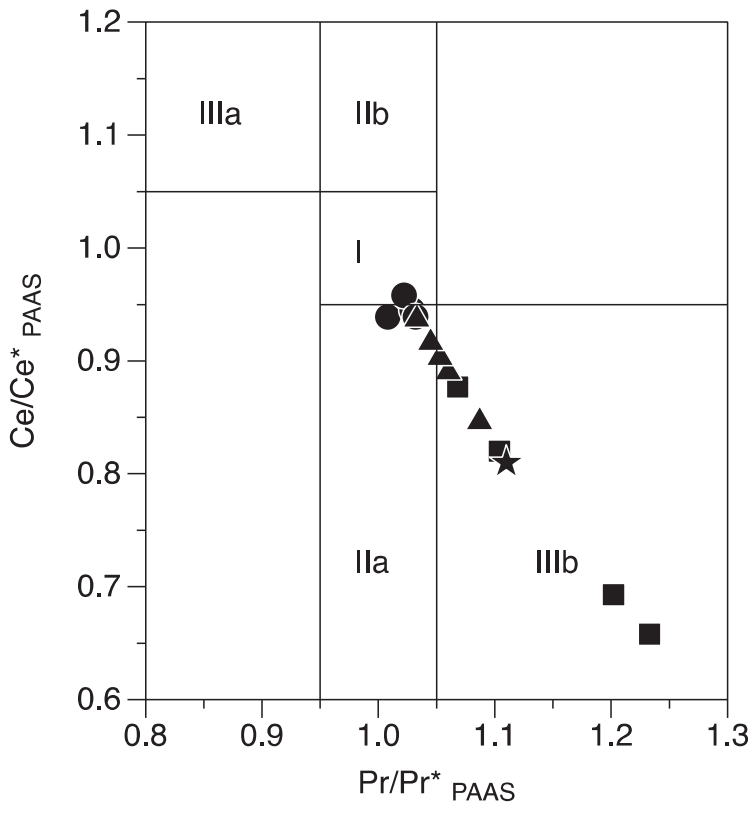

Fig. 6. Ce/Ce* vs. $\operatorname{Pr} / \operatorname{Pr}^{*}$. Field I, neither Ce nor La-anomaly, field IIa positive La-anomaly, no Ce-anomaly, field IIb negative Laanomaly, no Ce-anomaly, field IIIa: positive Ce-anomaly, field IIIb: negative Ce-anomaly. Except the cap carbonates (unit I: dots) most samples clearly plot in the field of negative Ce-anomalies.

negative $\mathrm{Ce}$-anomalies with $\mathrm{Ce} / \mathrm{Ce}^{*}$ between 0.71 and 0.92 for Doushantuo, and as low as 0.4 for carbonates from the overlying Dengying formation (551-543 Ma). Because modern oxidised seawater has a $\mathrm{Ce} / \mathrm{Ce}^{*}$ ratio $<0.55$, Ling et al. (2013) interpreted the Ediacaran data to indicate the existence of fully oxidized surface waters since the middle Dengying.

Using $\mathrm{Ce} / \mathrm{Ce}^{*}<0.9$ as indicator for real negative Ce-anomalies, we infer anoxic conditions (0.94-0.96) in unit I carbonate rocks, suboxic to oxic conditions in unit II (0.66-0.88) and suboxic to anoxic conditions in units III and IV (0.85-0.92 and 0.81 respectively) (Fig. 2). The only unit that might indicate oxic conditions is therefore unit II, which begins above a phosphoritic hardground at $21 \mathrm{~m}$ and which has been discussed as being part of a allochthonous slide sheet which may have originated at shallower slope or platform edge conditions (Vernhet et al., 2006, 2007).

\subsection{Origin of abundance variations of redox-sensitive elements}

In this section we highlight the role of redox sensitive trace elements (other than $\mathrm{Ce}$ ) and their enrichment in carbonates due to anoxic and presumably sulfidic pore-water conditions in the sediments.

Abundances of redox-sensitive metals in organic carbon rich shales and iron speciation in sediments have provided the main arguments in support of redox-stratified oceans during most of the Proterozoic (Li et al., 2010; Lyons et al. 2014). According to previous work late Proterozoic oceans may have had very different abundances of redox-sensitive trace elements compared to modern oxygenated seawater (e.g. Anbar and Knoll, 2002). It is debatable if carbonate rocks may reflect these compositional changes in seawater composition over time, as the influence of secondary diagenetic overprint and redistribution of redox sensitive elements by pore-waters have not been evaluated in detail so far.

Trace element variations in carbonates that formed in different environments are usually discussed in the reference frame of the trace element composition in known sediment compositions. For shales methods have been proposed for trace metals, by calculating the enrichment factor (EF) of an element relative to abundances in an average shale composite (Tribovillard et al., 2006). Here, we will use a similar approach but for the first time by comparison of the element enrichment in analysed samples to element abundances in a modern marine carbonate.

For shales, the enrichment factor of an element is usually calculated as following: $\mathrm{EF}_{\mathrm{El}}=\left(X_{\mathrm{El}} / \mathrm{Al}_{\mathrm{avg}}\right.$. shale $) /\left(X_{\mathrm{El}} \mathrm{Al}_{\text {sample }}\right)$, where $X$ is the concentration of the trace metal in the bulk rock and $\mathrm{Al}_{\text {avg shale }}$ and $\mathrm{Al}_{\text {sample }}$ are the concentrations of $\mathrm{Al}$ in the reference and the sample respectively. Due to acetic acid leaching of Yanwutan samples we are able to only calculate the enrichment factor of the trace elements in the carbonate phase. Relative to average shale all redox-sensitive elements $(\mathrm{Mn}, \mathrm{Mo}, \mathrm{U}, \mathrm{V})$ in the analysed carbonates show strong enrichment up to two to three orders of magnitude for most of the elements in unit I-III and up to four orders of magnitude for $\mathrm{Cd}$ and $\mathrm{Mo}$ in unit IV (Electronic Supplement Fig. D). Average shale represents an inappropriate normalisation standard for carbonates. This approach produces large uncertainties since carbonate rocks are characterized by very low siliciclastic input and acetic acid leachates of the carbonate fraction will underestimate concentrations of $\mathrm{Al}, \mathrm{K}$, Th and $\mathrm{Ti}$ in the bulk rock and thus distorts the ratios of elements with different chemical behaviour.

In this work we used a different approach by evaluating the enrichment of $\mathrm{Fe}, \mathrm{Mn}, \mathrm{Mo}, \mathrm{U}$ and $\mathrm{V}$ and the productivity tracers $\mathrm{Ba}, \mathrm{Zn}$ and $\mathrm{Cd}$ relative to the marine calcium carbonate standard Cal-S for which a broad range of trace element data is available (Yeghicheyan et al., 2003). The carbonate standard Cal-S is a micritic marine limestone, deposited on a shallow water platform at the Eastern border of the Parisian basin during the Tithonian. Cal-S has $\mathrm{REE}+\mathrm{Y}$ patterns comparable to modern oxidised seawater, showing negative Ce-anomalies and enrichment of HREE relative to LREE. This composition makes it a good material for comparison and evaluation of trace element enrichments in ancient carbonates. Enrichment factors are defined as follows: $\mathrm{EF}_{\mathrm{El}(\mathrm{CAL}-\mathrm{S})}=\left(X_{\mathrm{El}(\mathrm{HAsc})} / \mathrm{Al}_{(\mathrm{HAsc})}\right) /\left(X_{\mathrm{El}(\mathrm{CAL}-\mathrm{S})}\right)$ $\left.\mathrm{Al}_{(\mathrm{CAL}-\mathrm{S})}\right) \cdot X_{\mathrm{El}(\mathrm{HAsc})} / X_{\mathrm{El}(\mathrm{CAL}-\mathrm{S})}=$ concentration of redox sensitive element in leachate/reference material CAL-S;

$\mathrm{Al}_{(\mathrm{HAsc})} / \mathrm{Al}_{(\mathrm{CAL}-\mathrm{S})}=\mathrm{Al}$ concentration in leachate/reference material CAL-S. $\mathrm{EF}_{\mathrm{El}(\mathrm{CAL}-\mathrm{S})}>1$ indicates enrichment of element $X$ relative to modern seawater carbonate precipitates, values $<1$ indicate depletions (Fig. 7).

To test the influence of silicate phase input on redox sensitive element budgets in carbonate rocks we calculated $\mathrm{Al} / \mathrm{Ti}$ ratios. The modern shallow water carbonate standard Cal-S used for normalization has $84 \mu \mathrm{g} / \mathrm{g} \mathrm{Al}$ and $12 \mu \mathrm{g} / \mathrm{g}$ Ti 


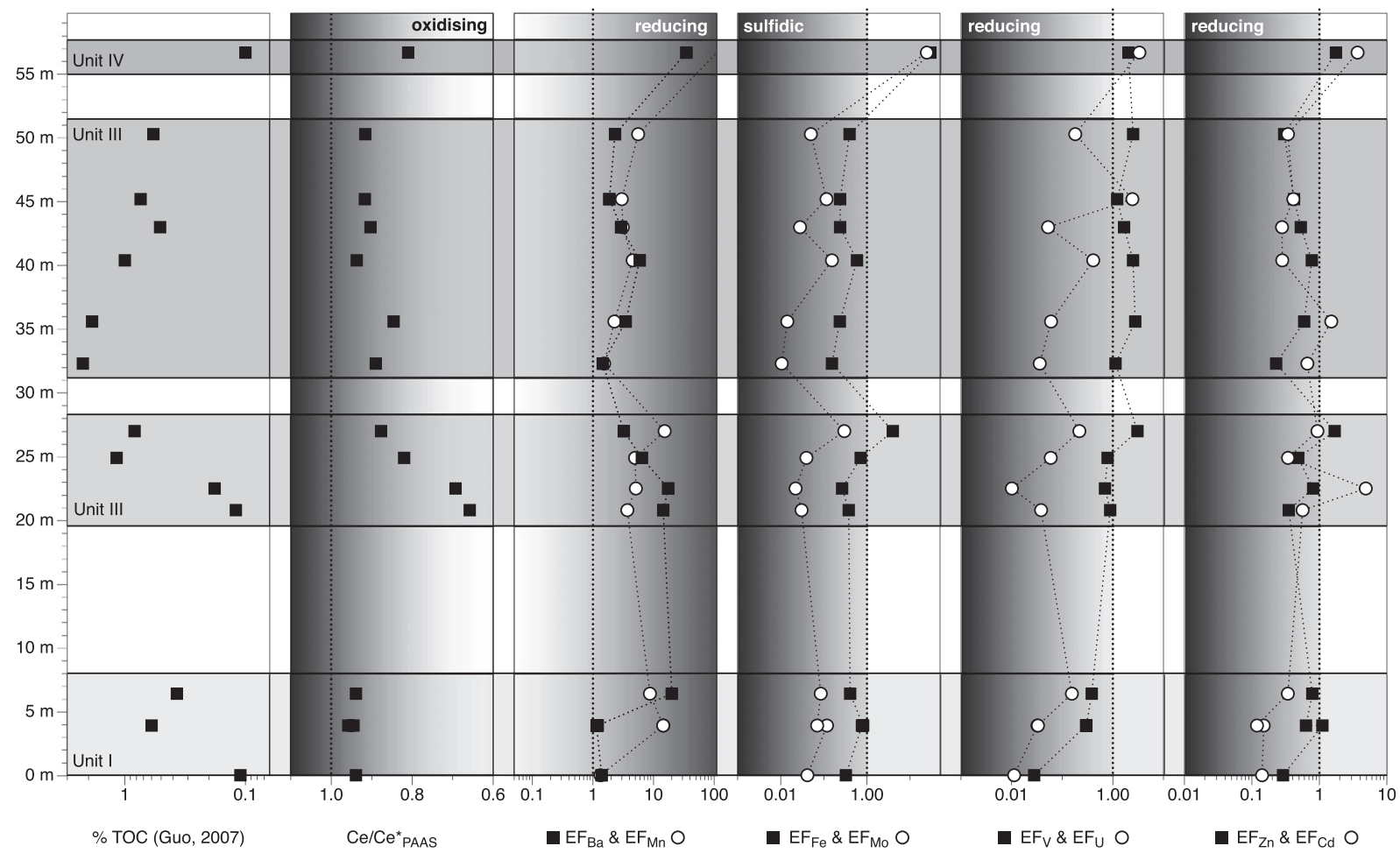

Fig. 7. TOC concentration $\mathrm{Ce} / \mathrm{Ce}^{*}$ ratios and enrichment factors (EF) of redox-sensitive elements $\mathrm{Mn}, \mathrm{Fe}, \mathrm{Mo}, \mathrm{U}$, V and productivity tracer elements ( $\mathrm{Ba}, \mathrm{Zn}, \mathrm{Cd}$ ) relative to Jurassic marine limestone CAL-S (=1, dotted line). EF scales are logarithmic. Most redox sensitive elements show no or minor enrichments such as for $\mathrm{V}$ from unit II upsection. Ba and $\mathrm{Mn}$ are strongly enriched in the samples relative to CAL-S reference material. Sample YAW 535 near the top of the section is strongly enriched in all elements but is also the sample with the lowest carbonate content of all samples. For definition of enrichment factors, see text.

and an $\mathrm{Al} / \mathrm{Ti}$ ratio of 7 . Carbonate leachates from Yanwutan yielded $\mathrm{Al} / \mathrm{Ti}$ ratios around 50 and show therefore a relative excess of aluminium, possibly due to the dissolution of detrital material, such as clay minerals and subsequent carbonate precipitation (Kryc et al., 2003). However the range of variations in the $\mathrm{Al}$ concentrations do not exceed those of other trace elements, hence, normalisation relative to the standard does not blur correlations of trace element abundances (Van Der Weijden, 2002). Furthermore there are no correlations of the redox sensitive elements with total $\mathrm{Al}$ concentrations nor with the variability in $\mathrm{Sr}$, Ba or oxygen isotope compositions, indicating that the redox sensitive elements have neither been influenced by leaching of silicates nor by late stage post-depositional fluid flow.

Enrichment factors of the redox-sensitive elements ( $\mathrm{Ba}$, $\mathrm{Mn}, \mathrm{Fe}, \mathrm{Mo}, \mathrm{U}, \mathrm{V}, \mathrm{Cd}$ and $\mathrm{Zn}$ ) show strong variability. In comparison to the carbonate standard Cal-S $\mathrm{Ba}$ and $\mathrm{Mn}$ are strongly enriched throughout the profile whereas the redox sensitive trace metals $\mathrm{V}, \mathrm{Mo}, \mathrm{U}, \mathrm{Fe}$ and the bioavailable metals $\mathrm{Zn}$ and $\mathrm{Cd}$ are significantly depleted within the carbonates of Yanwutan profile (with exception to the upper most unit IV). For Mo, V and U, enrichments in seawater precipitates such as carbonate rocks may indicate oxic to suboxic conditions in the waterbody or near the water/sediment interface since they behave soluble under reducing conditions and get trapped in non-carbonatic phases like black shales or black cherts (Emerson and Huested, 1991; Calvert and Pedersen, 1993; Tribovillard et al., 2006; Chang et al., 2009).

Depletion of Mo and $\mathrm{Fe}$ in carbonates may therefore be indicative for anoxic and even sulfidic conditions in the sediment body since accumulation of $\mathrm{Fe}$ in sediments usually occurs as iron sulphides, whereas under ferruginous conditions, $\mathrm{Fe}^{2+}$ may also be incorporated into carbonates (Canfield et al., 1993). Enrichment in Fe can only be seen on top of unit II and unit IV respectively. Fe and furthermore Mo depletion relative to modern carbonates $\left(\mathrm{EF}_{(\mathrm{Cal}-\mathrm{S})}<1\right)$ in Yanwutan samples would therefore argue for anoxic or even sulfidic pore-water conditions as Fe and Mo may have been incorporated into non-carbonatic phases such as sulphides.

$\mathrm{U}$ and $\mathrm{V}$ are depleted throughout the lower units of Yanwutan, with $\mathrm{V}$ being slightly enriched at the top from unit II up section. The depletion of $U$ may again be due to incorporation of the redox sensitive element in non-carbonatic phases, whereas $\mathrm{V}$ may be less susceptible to reducing pore-waters and therefor show enrichment factors above $1 \mathrm{~V}$ may therefore act as the first indicator for a shift to more oxic conditions in basinal bottom waters and slight oxygenation of the pore-water at the end of the Ediacaran, however Mo and Fe depletion at the same time still argue for the presence of $\mathrm{H}_{2} \mathrm{~S}$ in these units. 

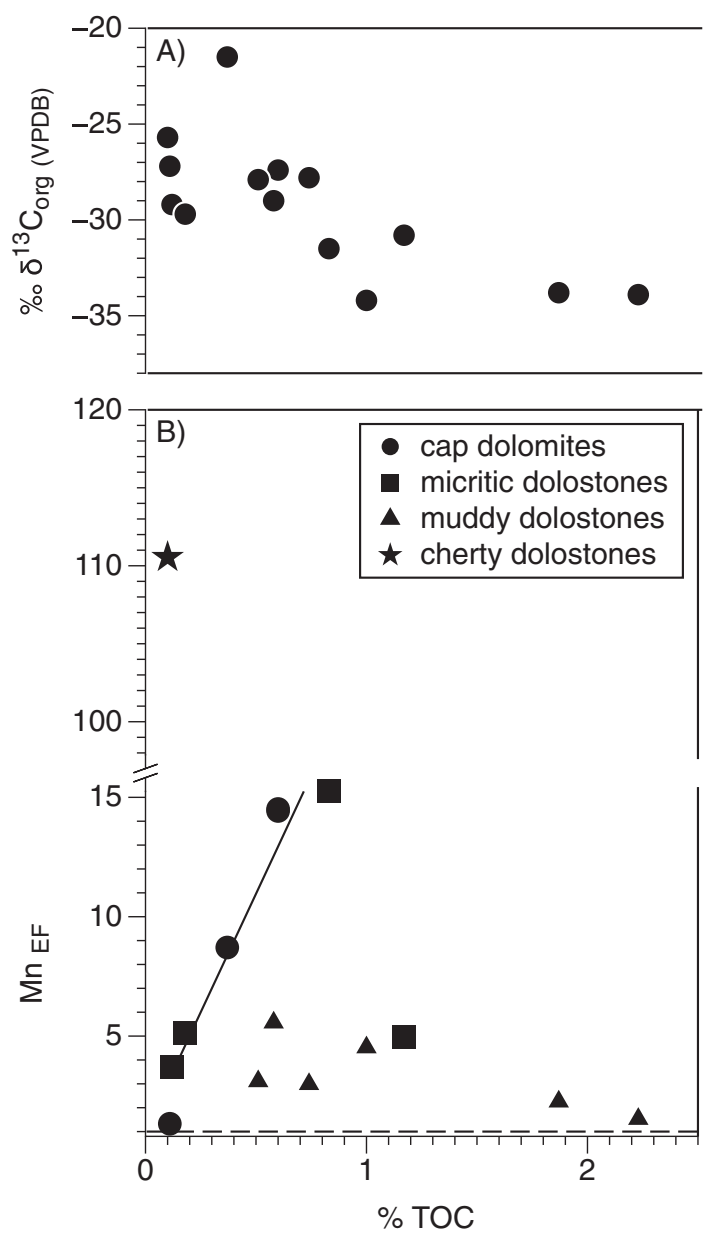

Fig. 8. (A) $\delta^{13} \mathrm{C}_{\text {org }}$ vs. TOC showing negative correlation. (B) Enrichment of Mn concentrations in acetic acid carbonate leachates relative to a pure carbonate standard vs. TOC in bulk rock. Note the weak positive correlation in units I and II (dots and squares, despite one outlier $R^{2}=0.93$ ) - a possible preserved signal of organic carbon rich $\mathrm{Mn}$ compounds getting dissolved and reprecipitated under reducing bottom/pore-water conditions.

Our observations match with recently published datasets from Brazilian Ediacaran sections, revealing generally low trace metal concentrations in marine sediments of the Araras platform at the same time of pyrite formation in presumably anoxic intervals (Sansjofre et al., 2014).

In Yanwutan carbonates the bioproductivity tracers $\mathrm{Ba}$, $\mathrm{Cd}$ and $\mathrm{Zn}$ yield enrichments towards the top of units I, II and IV for Zn and in some samples of unit II, III and IV for $\mathrm{Cd}$. Barium concentrations in the carbonate rocks are high, which may reflect the release of $\mathrm{Ba}$ into early pore-water during bacterial sulphide reduction under reducing conditions (Torres et al., 1996). It should be noted that Ba concentrations originally might have been even higher because they were at least partially affected by the fluid-mobile behaviour of $\mathrm{Ba}$ (Fig. 4 and discussion in Section 5.1).

Manganese as $\mathrm{Mn}^{2+}$ is thermodynamically unstable and precipitates under oxic conditions as Mn II or Mn IV oxide or hydroxide particulate matter (Bruland, 1983), scavenging other trace elements like REE, especially tetravalent
Cerium (Elderfield et al., 1988; Byrne and Kim, 1990; Alibo and Nozaki, 1999). Therefore modern stratified basins like the Black Sea or the Cariaco Trench show a decrease in $\mathrm{Mn}^{2+}$ concentrations in the oxygen rich surface layer and negative Ce-anomalies but under anoxic deep-water environments Mn oxides will redissolve and dissolved Mn concentrations in seawater increase, (de Baar et al., 1988; Lewis and Landing, 1991). Consequently, enrichment factors of $\mathrm{Mn}$ in carbonate leachates $<1$ should indicate Mn depletion in an oxic waterbody. In contrast, EF-Mn $n_{(\mathrm{CAL}-\mathrm{S})}>1$ would indicate an excess in dissolved $\mathrm{Mn}^{2+}$ due to the dissolution $\mathrm{Mn}$ bearing particles leading to local enrichments of $\mathrm{Mn}$ in carbonate sediments. Precipitation-dissolution processes of Mn species are prevalent in the water/sediment interface (Thomson et al., 1986). In the Yanwutan carbonate samples the Mn enrichment $\mathrm{EF}-\mathrm{Mn}_{(\mathrm{CAL}-\mathrm{S})}$ of units I and II correlate with an increase in TOC (Fig. 8b), which may indicate dissolution of organic matter associated Mn particulates under early diagenetic anoxic and maybe even sulfidic pore-water conditions.

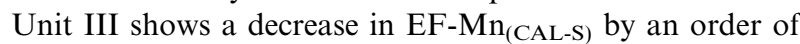
magnitude with gradually decreasing TOC values. While $\mathrm{EF}-\mathrm{V}_{(\mathrm{CAL}-\mathrm{S})}$ increases at the end of unit II above 1, $\mathrm{EF}-\mathrm{Mo}_{(\mathrm{CAL}-\mathrm{S})}$ and $\mathrm{EF}-\mathrm{Fe}_{(\mathrm{CAL}-\mathrm{S})}$ drop by almost one order of magnitude, indicating a decoupling of these elements and suggesting continued sulfidic conditions within the sediments. Lower enrichments in Mn in unit III argue for less reducing pore-water compositions during the deposition of unit III.

In contrast to the trace metal record arguing for reducing pore-water conditions at least the carbonates of unit II have preserved negative $\mathrm{Ce}$-anomalies as a record of oxic to suboxic conditions in the water column. As all carbonates preserve marine $\mathrm{REE}+\mathrm{Y}$ patterns, the $\mathrm{Ce}$-anomalies were most likely not lost by contact with reducing bottom or pore-waters.

Given the fact that unit II carbonates record negative $\delta$ ${ }^{13} \mathrm{C}_{\text {carb }}$ values ( -4 to -9$)$ we believe that they were deposited in deeper realms of the Yangtze Platform and not under shallow marine conditions as Vernhet et al. (2006) postulated. The negative Ce-anomalies of unit II would therefore argue for short intervals of suboxic to oxic conditions in the basin at still anoxic to sulfidic pore-water conditions in the sediments.

\subsection{Modell for the trace elemental budget in Yanwutan carbonates and effects of reducing pore-waters}

1. Development of seawater like REE $+Y$ patterns $\mathrm{REE}+\mathrm{Y}$ incorporation onto $\mathrm{Fe}$ and $\mathrm{Mn}$ oxides/hydroxides and organic compounds respectively. PAAS normalized REE $+\mathrm{Y}$ patterns of seawater will show HREE over LREE enrichment and if seawater was partially oxidised a negative $\mathrm{Ce}$ anomaly $\left(\mathrm{Ce} / \mathrm{Ce}^{*}<0.9\right)$ will be visible.

2. The precipitation of carbonates incorporates the $\mathrm{REE}+\mathrm{Y}$ signatures of the seawater.

3. Remobilization of trace elements under reducing pore-water conditions and incorporation in secondary non-carbonatic phases: 
Fe and Mo:

Under the presence of free $\mathrm{H}_{2} \mathrm{~S}$ (sulfidic pore-water conditions) $\mathrm{Fe}$ and Mo may be incorporated into sulfides.

$\mathrm{Ba}$ and $\mathrm{Mn}$ :

Reducing conditions (presumably with the help of bacterial sulfate reduction) can liberate labile $\mathrm{Ba}$ and Mn phases. Due to their fluid-mobile behaviour they will redistribute within the profile, eventually reprecipitating as Barite or $\mathrm{Ba}$ - and $\mathrm{Mn}$-rich carbonates along the redoxfront.

$V, U$ and the bioavailable redox metals like $\mathrm{Zn}$ and $C d$ :

The redox sensitive metals are soluble under reducing conditions. In consequence they get relatively depleted in the carbonate phases and commonly enrich in black-shales.

$R E E+Y$ :

The lanthanides concentrations within the carbonates may not be succeptible to reducing pore-water overprint as all acetic acid leachates show no correlated enrichment in redox sensitive elements and total REE concentrations. Furthermore all carbonates still preserve seawater-like REE $+\mathrm{Y}$ signatures and (most prominent in unit II) neagtive $\mathrm{Ce}$ anomalies, indicating oxidising conditions in the water collumn at the time of their precipitation.

On the basis of $\mathrm{Ce} / \mathrm{Ce}^{*}$, the water column of the basin sampled by carbonate sediments of the Yanwutan section was probably oxic (part of unit II) to suboxic/anoxic (unit III) during the Ediacaran, providing further arguments for anoxic conditions in deeper marine realms of the Yangtze basin between 635 and $551 \mathrm{Ma}$.

Throughout this time interval, sediments deposited in the basin were anoxic and even sulfidic, leading to a release of redox sensitive trace metals into the pore-waters and presumably capture of some Fe and Mo into sulfides.

The $\delta^{13} \mathrm{C}_{\text {carb }}$ data are decoupled from other tracers. We note that the negative and variable $\delta^{13} \mathrm{C}_{\text {carb }}$ in the cap dolomites may reflect alteration processes, however, the consistently negative values in units II to IV offer no indication for an origin by diagenetic alteration and fluid flow (in contrast to fluid-mobile elements such as $\mathrm{O}, \mathrm{Sr}$ and $\mathrm{Ba}$ ). Our data may support the ideas of a large DOC pool in the deep basin areas, which was oxidised as a result of bacterial activity (Ader et al., 2009). According to Ader et al., 2009 high TOC values and correspondingly low $\delta^{13} \mathrm{C}_{\mathrm{org}}$ in the lower Doushantuo of Yanwutan and Fengtan (Yuanling) sections might be explained by secondary productivity (e.g. activity of methanotrophs (Gong and Hollander, 1997; Hinrichs et al., 2000)) and limited organic matter mineralisation under anoxic conditions, and thus increasing the TOC and trace metal contents in sediments. The decoupling of $\delta^{13} \mathrm{C}_{\text {carb }}$ and $\delta^{13} \mathrm{C}_{\mathrm{org}}$ is most prominent in unit II of Yanwutan section (Ader et al., 2009), perhaps due to the partial oxidation of a large DOC pool as proposed for the Mid-Ediacaran Shuram-Woonoka anomaly (Fike et al., 2006). Unit III shows a slow return of $\delta^{13} \mathrm{C}_{\text {carb }}$ to less negative values $(-7)$ and the lowest $\delta^{13} \mathrm{C}_{\text {org }}$ of -34 .
Presumably, this reflects a higher oxidation potential, however, the absence of negative Ce-anomalies indicates that the formation conditions of the carbonates at that time remained anoxic.

\section{CONCLUSION}

Dolomitic rocks from the Doushantuo Formation at Yanwutan (Hunan, China) provide the rare opportunity to study a relatively coherent deep-water section of the Ediacaran on the Yangtze Platform. Compared to surface water carbonates all Yanwutan samples were precipitated from deep waters which were likely more enriched in ${ }^{12} \mathrm{C}$, in stark contrast to data from shallow water sections on the Yangtze Platform (e.g. Xiao et al., 2012). In most samples of the present work, diagenetic fluid-flow led to a substantial redistribution of fluid-mobile elements, notably, losses of $\mathrm{Sr}$ and $\mathrm{Ba}$, and addition of radiogenic $\mathrm{Sr}$ and light oxygen from typical continental basin fluids. In spite of the alteration of fluid-mobile elements, some samples, including the uppermost cap carbonate, display primary carbon isotope signatures that appear to reflect marine water compositions and processes in their original depositional environments and their evolution. As in shallow-water environments on the platform, cap dolomites were initially precipitated after the Marinoan glaciation. However, in contrast to platform settings Yanwutan cap dolomites show no negative Ce-anomalies, indicating anoxic depositional conditions and thus a chemically stratified water mass in the basin (Canfield, 1998; Li et al., 2010). A presumably partially allochthonous dolostone unit shows negative $\mathrm{Ce}$-anomalies which disappear towards the top consistent with carbonate precipitation under oxic to suboxic conditions.

Redox sensitive elements like Fe, Mo, $\mathrm{U}$ and $\mathrm{V}$ are depleted compared to Phanerozoic platform carbonates, whereas $\mathrm{Mn}$ and $\mathrm{Ba}$ are strongly enriched, suggesting anoxic and even sulfidic pore-water conditions, which may not have overprinted the partly negative $\mathrm{Ce}$ anomalies inherited from a precipitation in an suboxic to oxic seawaterbody. An increase in the abundances of redox sensitive elements towards the top of the Yanwutan section (especially in $\mathrm{V}$ concentrations) may indicate a change to less reducing conditions in the later Ediacaran. The trace element data and the decoupling of $\delta^{13} \mathrm{C}_{\text {carb }}$ from $\delta^{13} \mathrm{C}_{\text {org }}$ may be explained by the partial remineralisation of organic matter in the deep marine environment (Ader et al., 2009).

\section{ACKNOWLEDGMENTS}

This work was funded by the German Research Foundation (DFG Research Group FOR 736 "The Precambrian-Cambrian Biosphere Revolution: Insights from Chinese Microcontinents", subproject Be 1820/4-2). We thank Monika Feth and Konrad Hammerschmidt for their support in the lab and Members of FOR736 for their helpful comments and discussions, especially Christoph Heubeck for providing us sedimentologic feedback of the Yanwutan section. Furthermore we like to thank two anonymous reviewers for their constructive suggestions and help in structuring the final version of this article. 


\section{APPENDIX A. SUPPLEMENTARY DATA}

Supplementary data associated with this article can be found, in the online version, at http://dx.doi.org/10.1016/ j.gca.2015.04.037.

\section{REFERENCES}

Ader M., Macouin M., Trindade R. I. F., Hadrien M.-H., Yang Z., Sun Z. and Besse J. (2009) A multilayered water column in the Ediacaran Yangtze platform? Insights from carbonate and organic matter paired $\delta^{13}$ C. Earth Planet. Sci. Lett. 288, 213227.

Alibo D. S. and Nozaki Y. (1999) Rare earth elements in seawater: particle association, shale-normalization, and $\mathrm{Ce}$ oxidation. Geochim. Cosmochim. Acta 63, 363-372.

Anbar A. D. and Knoll A. H. (2002) Proterozoic ocean chemistry and evolution: a bioinorganic bridge? Science 297, 1137-1142.

Anbar A. D., Duan Y., Lyons T. W., Arnold G. L., Kendall B., Creaser R. A., Kaufman A. J., Gordon G. W., Scott C., Garvin J. and Buick R. (2007) A whiff of oxygen before the great oxidation event? Science 317, 1903-1906.

Banner J. L. (1988) Rare earth element and Nd isotopic variations in regionally extensive dolomites from the Burlington-Keokuk Formation (Mississippian): implications for Ree Mobility during carbonate diagenesis. J. Sediment. Res. 58.

Banner J. L. and Hanson G. N. (1990) Calculation of simultaneous isotopic and trace element variations during water-rock interaction with applications to carbonate diagenesis. Geochim. Cosmochim. Acta 54, 3123-3137.

Brand U. and Veizer J. (1980) Chemical diagenesis of a multicomponent carbonate system-1: trace elements. J. Sediment. Petrol. 50, 1-18.

Brand U. and Veizer J. (1981) Chemical diagenesis of a multicomponent carbonate system-2: stable isotopes. J. Sediment. Res. 51.

Bruland K. W. (1983) Trace elements in sea water. Chem. Oceanogr. 8, 158-220.

Byrne R. H. and Kim K. H. (1990) Rare earth element scavenging in seawater. Geochim. Cosmochim. Acta 54, 2645-2656.

Calvert S. E. and Pedersen T. F. (1993) Geochemistry of recent oxic and anoxic marine sediments: implications for the geological record. Mar. Geol. 113, 67-88.

Canfield D. E. (1998) A new model for Proterozoic ocean chemistry. Nature 396, 453.

Canfield D. E., Thumdrup B. and Hansen J. W. (1993) The anaerobic degradation of organic matter in Danish coastal sediments: Iron reduction, manganese reduction, and sulfate reduction. Geochim. Cosmochim. Acta 57, 3867-3883.

Canfield D. E., Poulton S. W. and Narbonne G. M. (2007) LateNeoproterozoic deep-ocean oxygenation and the rise of animal life. Science 315, 92-95.

Chang H., Chu X., Feng L. and Huang J. (2009) Terminal Ediacaran anoxia in deep-ocean: trace element evidence from cherts of the Liuchapo Formation, South China. Sci. China Ser. D-Earth Sci. 52, 807-822.

Chen J. and Chi H. (2005) Precambrian phosphatized embryos and larvae from the Doushantuo Formation and their affinities, Guizhou (SW China). Chin. Sci. Bull. 50, 2193-2200.

Cherniak D. J. (1998) REE diffusion in calcite. Earth Planet. Sci. Lett. 160, 273-287.

Condon D., Zhu M., Bowring S., Wang W., Yang A. and Jin Y. (2005) U-Pb Ages from the Neoproterozoic Doushantuo Formation, China. Science 308, 95-98.

de Baar H. J. W., German C. R., Elderfield H. and van Gaans P. (1988) Rare earth element distributions in anoxic waters of the Cariaco Trench. Geochim. Cosmochim. Acta 52, 1203-1219.
Derkowski A., Bristow T. F., Wampler J. M., Środoń J., Marynowski L., Elliott W. C. and Chamberlain C. P. (2013) Hydrothermal alteration of the Ediacaran Doushantuo Formation in the Yangtze Gorges area (South China). Geochim. Cosmochim. Acta 107, 279-298.

Derry L. A. (2010) On the significance of $\delta^{13} \mathrm{C}$ correlations in ancient sediments. Earth Planet. Sci. Lett. 296, 497-501.

Derry L. A. and Jacobsen S. B. (1990) The chemical evolution of Precambrian seawater: evidence from REEs in banded iron formations. Geochim. Cosmochim. Acta 54, 2965-2977.

Derry L. A., Keto L. S., Jacobsen S. B., Knoll A. H. and Swett K. (1989) Sr isotopic variations in Upper Proterozoic carbonates from Svalbard and East Greenland. Geochim. Cosmochim. Acta 53, 2331-2339.

Dulski P. (1994) Interferences of oxide, hydroxide and chloride analyte species in the determination of rare earth elements in geological samples by inductively coupled plasma-mass spectrometry. Fresenius J. Anal. Chem. 350, 194-203.

Elderfield H., Whitfield M., Burton J. D., Bacon M. P. and Liss P. S. (1988) The oceanic chemistry of the rare-earth elements [and discussion]. Philos. Trans. R. Soc. Lond. Ser. Math. Phys. Sci. 325(1583), 105-126.

Emerson S. R. and Huested S. S. (1991) Ocean anoxia and the concentrations of molybdenum and vanadium in seawater. Mar. Chem. 34, 177-196.

Fike D. A., Grotzinger J. P., Pratt L. M. and Summons R. E. (2006) Oxidation of the Ediacaran ocean. Nature 444, 744-747.

Font E., Nédélec A., Trindade R. I. F. and Moreau C. (2010) Fast or slow melting of the Marinoan snowball Earth? The cap dolostone record. Palaeogeogr. Palaeoclimatol. Palaeoecol. 295, 215-225.

German C. R., Holliday B. P. and Elderfield H. (1991) Redox cycling of rare earth elements in the suboxic zone of the Black Sea. Geochim. Cosmochim. Acta 55, 3553-3558.

Gong C. and Hollander D. J. (1997) Differential contribution of bacteria to sedimentary organic matter in oxic and anoxic environments, Santa Monica Basin, California. Org. Geochem. 26, 545-563.

Guo Q., Strauss H., Liu C., Goldberg T., Zhu M., Pi D., Heubeck C., Vernhet E., Yang X. and Fu P. (2007) Carbon isotopic evolution of the terminal Neoproterozoic and early Cambrian: evidence from the Yangtze Platform, South China. Palaeogeogr. Palaeoclimatol. Palaeoecol. 254, 140-157.

Halverson G. P., Hoffman P. F., Schrag D. P., Maloof A. C. and Rice A. H. N. (2005) Toward a Neoproterozoic composite carbon-isotope record. Geol. Soc. Am. Bull. 117, 1181-1207.

Halverson G. P., Wade B. P., Hurtgen M. T. and Barovich K. M. (2010) Neoproterozoic chemostratigraphy. Precambr. Res. 182, $337-350$.

Hinrichs K.-U., Summons R. E., Orphan V., Sylva S. P. and Hayes J. M. (2000) Molecular and isotopic analysis of anaerobic methane-oxidizing communities in marine sediments. Org. Geochem. 31, 1685-1701.

Hoffman P. F., Kaufman A. J., Halverson G. P. and Schrag D. P. (1998) A Neoproterozoic snowball Earth. Science 281, 1342 1346.

Huang J., Chu X., Chang H. and Feng L. (2009) Trace element and rare earth element of cap carbonate in Ediacaran Doushantuo Formation in Yangtze Gorges. Chin. Sci. Bull. 54, 3295-3302.

Huang J., Ganjing J. and XueLei C. (2011) Hydrothermal origin of elevated iron, manganese and redox-sensitive trace elements in the c. $635 \mathrm{Ma}$ Doushantuo cap carbonate. J. Geol. Soc. $\mathbf{1 6 8}$, $805-816$.

Hyde W. T., Crowley T. J., Baum S. K. and Peltier W. R. (2000) Neoproterozoic snowball Earth simulations with a coupled climate/ice-sheet model: Abstract: Nature. Nature 405, 425429. 
Jacobsen S. B. and Kaufman A. J. (1999) The Sr, C and O isotopic evolution of Neoproterozoic seawater. Chem. Geol. 161, $1-21$.

Jiang G., Kennedy M. J. and Christie-Blick N. (2003) Stable isotopic evidence for methane seeps in Neoproterozoic postglacial cap carbonates. Nature 426, 822-826.

Jiang S.-Y., Chen Y.-Q., Ling H.-F., Yang J.-H., Feng H.-Z. and Ni P. (2006) Trace- and rare-earth element geochemistry and $\mathrm{Pb}-\mathrm{Pb}$ dating of black shales and intercalated $\mathrm{Ni}-\mathrm{Mo}-\mathrm{PGE}-\mathrm{Au}$ sulfide ores in Lower Cambrian strata, Yangtze Platform, South China. Miner. Deposita 41, 453-467.

Jiang G., Kaufman A. J., christie-Blick N., Zhang S. and Wu H. (2007) Carbon isotope variability across the Ediacaran Yangtze platform in South China: implications for a large surface-todeep ocean $\delta^{13} \mathrm{C}$ gradient. EPSL 261, 303-320.

Jiang G., Shi X., Zhang S., Wang Y. and Xiao S. (2011) Stratigraphy and paleogeography of the Ediacaran Doushantuo Formation (ca. 635-551 Ma) in South China. Gondwana Res. 19, 831-849.

Kasemann S. A., Hawkesworth C. J., Prave A. R., Fallick A. E. and Pearson P. N. (2005) Boron and calcium isotope composition in Neoproterozoic carbonate rocks from Namibia: evidence for extreme environmental change. Earth Planet. Sci. Lett. 231, 73-86.

Kaufman A. J. and Knoll A. H. (1995) Neoproterozoic variations in the C-isotopic composition of seawater: stratigraphic and biogeochemical implications. Precambr. Res. 73, 27-49.

Kaufman A. J., Knoll A. H. and Narbonne G. M. (1997) Isotopes, ice ages, and terminal Proterozoic earth history. Proc. Natl. Acad. Sci. 94, 6600-6605.

Kennedy M., Mrofka D. and Borch von der C. (2008) Snowball Earth termination by destabilization of equatorial permafrost methane clathrate. Nature 453, 642-645.

Knauth L. P. and Kennedy M. J. (2009) The late Precambrian greening of the Earth. Nature 460, 728-732.

Kryc K. A., Murray R. W. and Murray D. W. (2003) Al-to-oxide and Ti-to-organic linkages in biogenic sediment: relationships to paleo-export production and bulk Al/Ti. Earth Planet. Sci. Lett. 211, 125-141.

Lawrence M. G. and Kamber B. S. (2006) The behaviour of the rare earth elements during estuarine mixing-revisited. Mar. Chem. 100, 147-161.

Le Hir G., Donnadieu Y., Goddéris Y., Pierrehumbert R. T., Halverson G. P., Macouin M., Nédélec A. and Ramstein G. (2009) The snowball Earth aftermath: exploring the limits of continental weathering processes. Earth Planet. Sci. Lett. 277, 453-463.

Lewis B. L. and Landing W. M. (1991) The biogeochemistry of manganese and iron in the Black-Sea. Deep-Sea Res. 38, 773803.

Li C., Love G. D., Lyons T. W., Fike D. A., Sessions A. L. and Chu X. (2010) A stratified redox model for the Ediacaran ocean. Science 328, 80-83.

Li D., Ling H. F., Shields-Zhou G. A. and Chen X. (2013) Carbon and strontium isotope evolution of seawater across the Ediacaran-Cambrian transition: Evidence from the Xiaotan section, NE Yunnan, South China. Precambr. Res. 225, 128147.

Ling H. F., Chen X., Li D., Wang D. and Shields-Zhou G. A. (2013) Cerium anomaly variations in Ediacaran-earliest Cambrian carbonates from the Yangtze Gorges area, South China: implications for oxygenation of coeval shallow seawater. Precambr. Res. 225, 110-127.

Lyons T. W., Reinhard C. T. and Planavsky N. J. (2014) The rise of oxygen in Earth's early ocean and atmosphere. Nature 506, $307-315$.
Macouin M., Ader M., Moreau M. G. and Poitou C. (2012) Deciphering the impact of diagenesis overprint on negative $\delta^{13} \mathrm{C}$ excursions using rock magnetism: case study of Ediacaran carbonates, Yangjiaping section, South China. Earth Planet. 351-352, 281-294.

McFadden K. A., Huang J., jiang G., Kaufman A. J. and chu X. (2008) Pulsed oxidation and biological evolution in the Ediacaran Doushantuo Formation. Proc. Natl. Acad. Sci. 105, 3197-3202.

McLennan S. M. (1989) Rare earth elements in sedimentary rocks: Influence of provenance and sedimentary processes. Geochem. Mineral. Rare Earth Elem. 21, 169-200.

Nier A. (1938) The Isotopic Constitution of Strontium, Barium, Bismuth, Thallium and Mercury. Phys. Rev. 54, 275-278.

Nogueira A., Riccomini C., Sial A., Moura C., Trindade R. and Fairchild T. (2007) Carbon and strontium isotope fluctuations and paleoceanographic changes in the late Neoproterozoic Araras carbonate platform, southern Amazon craton, Brazil. Chem. Geol. 237, 168-190.

Nothdurft L. D., Webb G. E. and Kamber B. S. (2004) Rare earth element geochemistry of Late Devonian reefal carbonates, Canning Basin, Western Australia: confirmation of a seawater REE proxy in ancient limestones. Geochim. Cosmochim. Acta 68, 263-283.

Nozaki Y., Zhang J. and Amakawa H. (1997) The fractionation between $\mathrm{Y}$ and $\mathrm{Ho}$ in the marine environment. Earth Planet. Sci. Lett. 148, 329-340.

Och L. M. and Shields-Zhou G. A. (2012) The Neoproterozoic oxygenation event: Environmental perturbations and biogeochemical cycling. Earth-Sci. Rev. 110, 26-57.

Palmer M. R. (1985) Rare earth elements in foraminifera tests. Earth Planet. Sci. Lett. 73, 285-298.

Sahoo S. K., Planavsky N. J., Kendall B., Wang X. and Shi X. (2012) Ocean oxygenation in the wake of the Marinoan glaciation. Nature 489, 546-549.

Sansjofre P., Ader M., Trindade R. I. F., Elie M., Lyons J., Cartigny P. and Nogueira A. C. R. (2011) A carbon isotope challenge to the snowball Earth. Nature 478, 93-96.

Sansjofre P., Trindade R. I. F., Ader M., Soares J. L., Nogueira A. C. R. and Tribovillard N. (2014) Paleoenvironmental reconstruction of the Ediacaran Araras platform (Western Brazil) from the sedimentary and trace metals record. Precambr. Res. 241, 185-202.

Sawaki Y., Ohno T., Tahata M., komiya T., Hirata T., Maruyama S., Windley B. F., Han J., Shu D. and Li Y. (2010) The Ediacaran radiogenic $\mathrm{Sr}$ isotope excursion in the Doushantuo Formation in the Three Gorges area, South China. Precambr. Res. 176, 46-64.

Scott C., Lyons T. W., Bekker A., Shen Y., Poulton S. W., Chu X. and Anbar A. D. (2008) Tracing the stepwise oxygenation of the Proterozoic ocean. Nature 452, 456-459.

Shields G. and Stille P. (2001) Diagenetic constraints on the use of cerium anomalies as palaeoseawater redox proxies: an isotopic and REE study of Cambrian phosphorites. Chem. Geol. 175, $29-48$.

Sholkovitz E. and Shen G. T. (1995) The incorporation of rare earth elements in modern coral. Geochim. Cosmochim. Acta 59, 2749-2756.

Stoll H. M. and Schrag D. P. (2000) High-resolution stable isotope records from the Upper Cretaceous rocks of Italy and Spain: glacial episodes in a greenhouse planet? Geol. Soc. Am. Bull. 112, 308-319.

Tahata M., Ueno Y., Ishikawa T., Sawaki Y., Murakami K., Han J., Shu D., Li Y., Guo J., Yoshida N. and Komiya T. (2013) Carbon and oxygen isotope chemostratigraphies of the Yangtze platform, South China: Decoding temperature and 
environmental changes through the Ediacaran. Gondwana Res. 23, 333-353.

Thomson J., Higgs N. C., Jarvis I. and Hydes D. J. (1986) The behaviour of manganese in Atlantic carbonate sediments. Geochim. Cosmochim. Acta 50, 1807-1818.

Torres M. E., Brumsack H. J., Bohrmann G. and Emeis K. C. (1996) Barite fronts in continental margin sediments: a new look at barium remobilization in the zone of sulfate reduction and formation of heavy barites in diagenetic fronts. Chem. Geol. 127, 125-139.

Tribovillard N., Algeo T. J., Lyons T. and Riboulleau A. (2006) Trace metals as paleoredox and paleoproductivity proxies: An update. Chem. Geol. 232, 12-32.

Trindade R. I. F., Font E., D’Agrella Filho M. S., Nogueira A. C. R. and Riccomini C. (2003) Low-latitude and multiple geomagnetic reversals in the Neoproterozoic Puga cap carbonate, Amazon craton. Terra Nova 15, 441-446.

Van Der Weijden C. H. (2002) Pitfalls of normalization of marine geochemical data using a common divisor. Mar. Geol. 184, 167187.

Van Lith Y., Warthmann R., Vasconcelos C. and Mckenzie J. A. (2003) Microbial fossilization in carbonate sediments: a result of the bacterial surface involvement in dolomite precipitation. Sedimentology 50, 237-245.

Vernhet E., Heubeck C., Zhu M. Y. and Zhang J. M. (2006) Largescale slope instability at the southern margin of the Ediacaran Yangtze platform (Hunan province, central China). Precambr. Res. 148, 32-44.

Vernhet E. (2007) Paleobathymetric influence on the development of the late Ediacaran Yangtze platform (Hubei, Hunan, and Guizhou provinces, China). Sed. Geol. 197, 29-46.

Vernhet E., Heubeck C., Zhu M. Y. and Zhang J. M. (2007) Stratigraphic reconstruction of the Ediacaran Yangtze platform margin (Hunan province, China) using a large olistolith. Palaeogeogr. Palaeoclimatol. Palaeoecol. 254, 123-139.
Wang J. and Li Z. X. (2003) History of Neoproterozoic rift basins in South China: implications for Rodinia break-up. Precambr. Res. 122, 141-158.

Webb G. E. and Kamber B. S. (2000) Rare earth elements in Holocene reefal microbialites: a new shallow seawater proxy. Geochim. Cosmochim. Acta 64, 1557-1565.

Webb G. E., Nothdurft L. D., Kamber B. S., Koprogge J. T. and Zhao J.-X. (2009) Rare earth element geochemistry of scleractinian coral skeleton during meteoric diagenesis: a sequence through neomorphism of aragonite to calcite. Sedimentology 56, 1433-1463.

Xiao S., McFadden K. A., Peek S. and Kaufman A. J. (2012) ScienceDirect.com - Precambrian Research - Integrated chemostratigraphy of the Doushantuo Formation at the northern Xiaofenghe section (Yangtze Gorges, South China) and its implication for Ediacaran stratigraphic correlation and ocean redox models. Precambr. Res. 192-195, 125-141.

Yeghicheyan D., Carignan J., Valladon M., Bouhnik Le Coz M., Samuel J., BenBakkar M., Bruguier O., Keller F., Pin C., Pourtales L., He' nin O., Mace' J., Morin N., Guilmette C. and Marin L. (2003) The new carbonate reference material Cal-S: preliminary results. Abs. Geoanal. 2003, 146.

Yuan X., Xiao S., Yin L., Knoll A. H., Zhou C. and Mu X. (2002) Doushantuo Biota: A Window on Early Multicellular Life. Chinese Scientific and Technological University Press, Shengzhen, China.

Zhao Y.-Y., Zheng Y.-F. and Chen F. (2009) Trace element and strontium isotope constraints on sedimentary environment of Ediacaran carbonates in southern Anhui, South China. Chem. Geol. 265, 345-362.

Zhao Z. (1985) Biostratigraphy of the Yangtze Gorge Area. Sinian 1, 1-169. 